This document was prepared in conjunction with work accomplished under Contract No. DE-AC09-96SR18500 with the U.S. Department of Energy.

This work was prepared under an agreement with and funded by the U.S. Government. Neither the U. S. Government or its employees, nor any of its contractors, subcontractors or their employees, makes any express or implied: 1 . warranty or assumes any legal liability for the accuracy, completeness, or for the use or results of such use of any information, product, or process disclosed; or 2 . representation that such use or results of such use would not infringe privately owned rights; or 3 . endorsement or recommendation of any specifically identified commercial product, process, or service. Any views and opinions of authors expressed in this work do not necessarily state or reflect those of the United States Government, or its contractors, or subcontractors. 
WSRC-STI-2007-00127, Rev. 1

$5 / 4 / 2007$

1 of 21

\title{
HOLDUP MEASUREMENTS FOR THREE VISUAL EXAMINATION and TRU REMEDIATION GLOVEBOX FACILITIES AT THE SAVANNAH RIVER SITE
}

\author{
R.A. Dewberry, V. R. Casella, R.A. Sigg, S. R. Salaymeh, F. S. Moore, and D. J. Pak \\ Savannah River National Laboratory \\ Aiken, SC 29808
}

\begin{abstract}
Visual Examination (VE) gloveboxes are used to remediate transuranic waste (TRU) drums at three separate facilities at the Savannah River Site. Noncompliant items are removed before the drums undergo further characterization in preparation for shipment to the Waste Isolation Pilot Plant (WIPP). Maintaining the flow of drums through the remediation process is critical to the program's seven-daysper-week operation. Conservative assumptions are used to ensure that glovebox contamination from this continual operation is below acceptable limits. Holdup measurements using cooled HPGe spectrometers are performed in order to confirm that these assumptions are conservative.

${ }^{239} \mathrm{Pu}$ is the main nuclide of interest; however, ${ }^{241} \mathrm{Pu}$, equilibrium ${ }^{237} \mathrm{~Np} /{ }^{233} \mathrm{~Pa}$ and ${ }^{238} \mathrm{Pu}$ (if detected) are typically assayed. At the Savannah River National Laboratory (SRNL) facility ${ }^{243,244,245} \mathrm{Cm}$ are also generally observed and are always reported at either finite levels or at limits of detection. A complete assay at each of the three facilities includes a measure of TRU content in the gloveboxes and HEPA filters in the glovebox exhaust.
\end{abstract}

This paper includes a description of the $\gamma$-PHA acquisitions, of the modeling, and of the calculations of nuclide content. Because each of the remediation facilities is unique and ergonomically unfavorable to $\gamma$-ray acquisitions, we have constructed custom detector support devices specific to each set of acquisitions. This paper includes a description and photographs of these custom devices. The description of modeling and calculations include determination and application of container and matrix photon energy dependent absorption factors and also determination and application of geometry factors relative to our detector calibration geometry.

The paper also includes a discussion of our measurements' accuracy using off-line assays of two SRNL HEPA filters. The comparison includes assay of the filters inside of 55-gallon drums using the SRNL $Q^{2}$ assay system and separately using off-line assay with an acquisition configuration unique from the original in-situ acquisitions.

\section{Introduction}

This report describes experimental $\gamma$-ray acquisitions and calculations to perform TRU holdup measurements in the three remediation glovebox facilities at SRS that operate in support of solid waste management. The three facilities are the Solid Waste Pad 6 Visual Evaluation (VE) glovebox, the Solid Waste Pad 19 Modular Remediation System (MRS) glovebox, and the SRNL TRU drum remediation glovebox. Each of these three glovebox trains is designed to support qualification of solid waste for shipping 55-gallon TRU drums to the Waste Isolation Pilot Plant (WIPP). To be qualified for acceptance by WIPP as TRU waste, a drum must contain greater than $100 \mathrm{nCi} / \mathrm{g}$ of transuranic waste and must include only solid waste that meets the waste acceptance criteria. TRU species are defined as having a radioactive half-life greater than 20 years and an atomic number greater than 92. Examples of items that 
WSRC-STI-2007-00127, Rev. 1

$5 / 4 / 2007$

2 of 21

do not meet the TRU waste acceptance criteria include sealed containers greater than four liters and liquid that is greater than $1 \%$ of the total drum volume or greater than $1 \%$ of the primary container volume. ${ }^{1,2}$

The Pad 6 Visual Evaluation glovebox was built to provide a containment facility for opening 55-gallon drums designated as TRU waste in order to evaluate the contents for prohibited items. The Pad 19 MRS remediation facility and the SRNL remediation facility were built to accommodate removal of prohibited items from solid waste drums so that the drums can be repackaged as qualified TRU waste. Qualified TRU drums are then assayed using passive $\gamma$-ray pulse height evaluation to determine TRU content (i.e. less than or greater than $100 \mathrm{nCi} / \mathrm{g}$ ). When requested, liquid samples removed from non-compliant drums are assayed in a doubly-contained drum-in-drum configuration for determination of SNM and radioactive content. The SRNL Nuclear Measurement group has kept four measurement systems specifically efficiency calibrated and continually ready for these assays. ${ }^{3-5}$ Sample specific geometry and selfabsorption corrections are implemented using the Ortec ISOTOPIC analysis code. ${ }^{6}$

Maintaining the flow of drums through the remediation process is critical to the program's seven-daysper-week operation. Facility operators currently assume that $90 \%$ of the radionuclide inventory in a drum leaves the glovebox following remediation. After a sufficient number of drums are processed, the $10 \%$ radionuclide concentration that is assumed to remain in the glovebox is assayed through holdup measurements in order to assure continued safe operation. Waste Management Engineering requests SRNL to perform these measurements in order to enable the gloveboxes to return to service as soon as possible. Since 2003 the Analytical Development field nuclear measurement group of SRNL has performed these holdup assays and calculations dozens of times to support the three facilities. Always the results have been reported within 24 hours, and frequently we have accomplished morning acquisitions and afternoon reporting. The assumption of $10 \%$ residual holdup has never been violated (i.e. never exceeded), and the holdup acquisitions and analyses have never delayed drum processing.

\section{Measurement Process}

The objective of each of the holdup measurements in the three remediation and visual inspection facilities is to obtain a process control determination of fissile material content to assure continued operation within the prescribed safety basis. ${ }^{7}$ It has never been necessary to report an exact measurement of fissile content. Rather, a conservative bounding upper limit of content is all that has been requested by Solid Waste Management. We have adopted a prescribed methodology for the passive $\gamma$-ray acquisitions and analyses that yields a defensible upper limit of content. For all acquisitions a collimated HPGe detector was placed on a stand that positioned the detector at the positions very much like those shown schematically in Figures 1 and 2. Each of the acquisition points had the common acquisition distances

- 10 inches above the glovebox floor,

- 10 inches from the face of the glovebox, and

- 7.5 inches from the HEPA filters. 
WSRC-STI-2007-00127, Rev. 1

$5 / 4 / 2007$

3 of 21

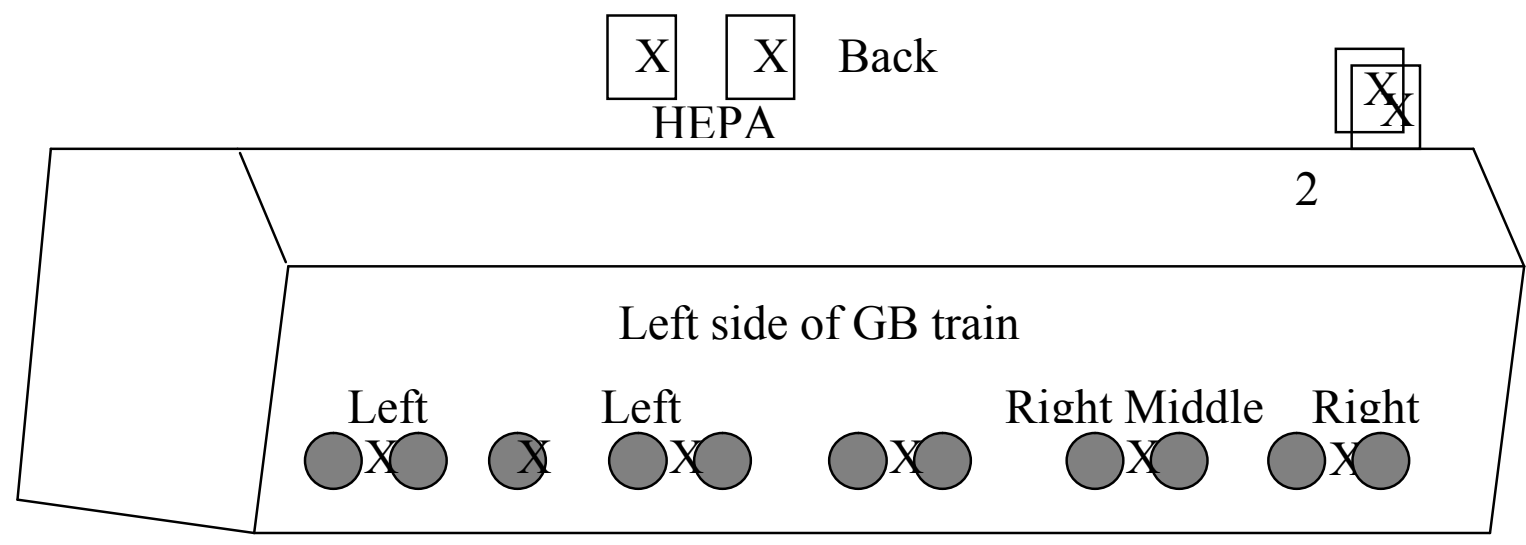

Figure 1. Maintenance Side Pad 19 Acquisition Points. GB positions (on front and same positions on back of GB train) and HEPAs assayed are designated by $X$.

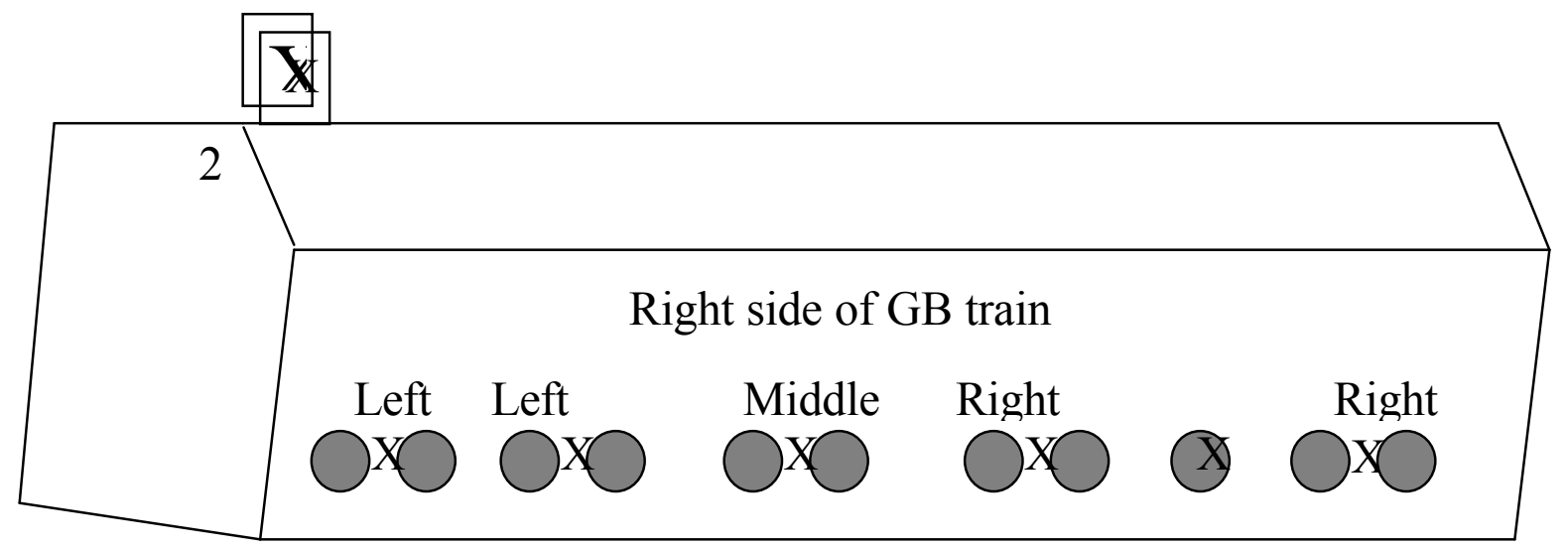

Figure 2. Operator Side Pad 19 Acquisition Points. GB positions (on front and same positions on back of GB train) and HEPAs assayed are designated by $X$.

Spectra are collected for 10 minutes at each acquisition point. All of the glovebox spectra then have identical acquisition parameters and all of the HEPA filter spectra have identical acquisition parameters. The detectors used differ for each facility. Acquired spectra are analyzed off-line using the ISOTOPIC analysis code with efficiency calibrations specific to each of the detectors and collimators. We describe the analyses in more detail below.

The glovebox assay positions were selected so that the detector fields of view obtain overlapping coverage of the opposite wall of the glovebox. These fields of view were determined using the tool provided by the ISOTOPIC code. An example is shown in Figure 3. For each of the three remediation facilities, the fields of view form overlapping coverage of the opposite wall of the glovebox and form approximately complete coverage of the glovebox floor. For the MRS drum facility and for the SRNL drum remediation facility the holdup measurements include acquisitions from both sides of the gloveboxes. Therefore the whole glovebox floor is assayed and both walls of the gloveboxes are assayed 
WSRC-STI-2007-00127, Rev. 1

$5 / 4 / 2007$

4 of 21

with overlapping coverage as "opposite" walls. We describe the Pad 6 VE facility acquisitions in a little more detail below.

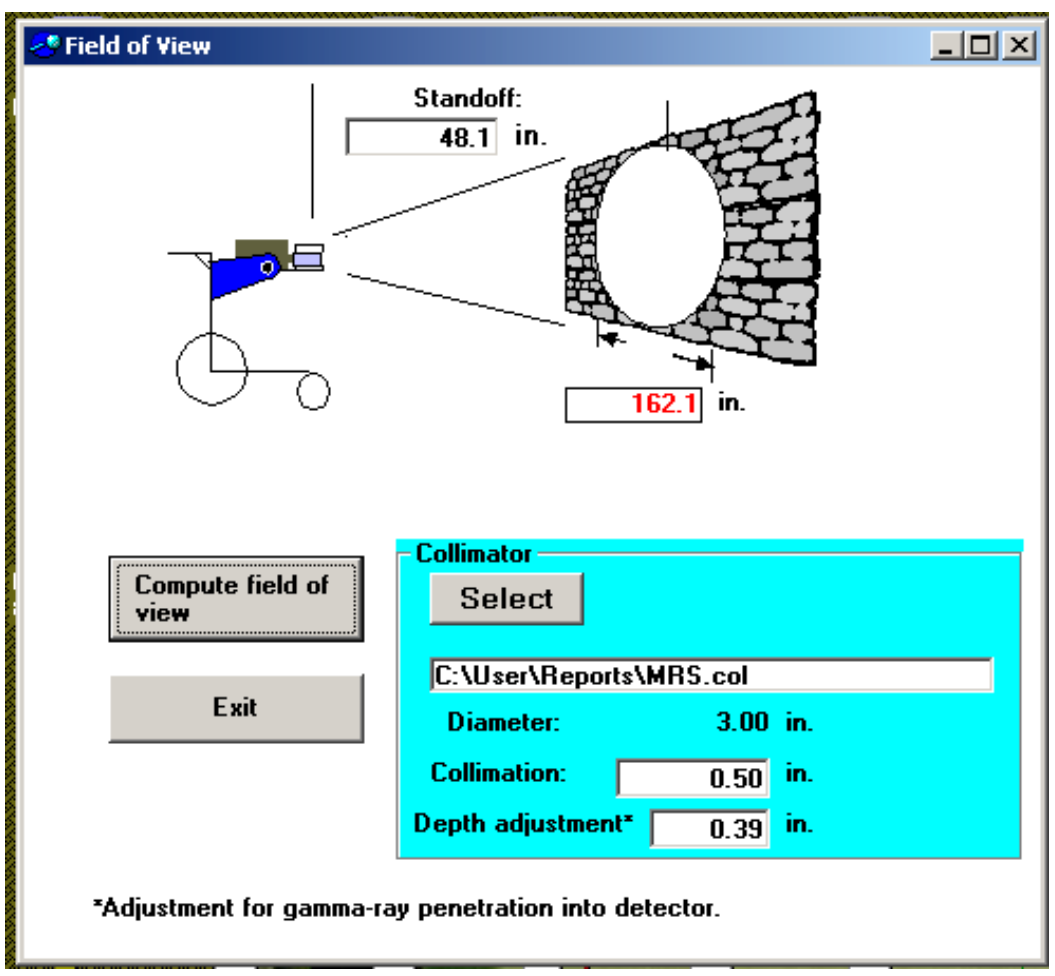

Figure 3. Example field of view.

In the glovebox data analyses, all of the observed activity is taken to be originating from the opposite wall in each acquisition. This overestimates the acquisition distance on average, because activity observed from the glovebox floor and from the "front" wall has a shorter source to detector distance than activity truly observed from the opposite wall. With this assumption the overestimated acquisition distance yields a conservative positive bias in the resulting calculation when converting observed activity to calculated holdup. This technique of determination uses the ISOTOPIC code "glovebox back" calculation configuration and assures our measurement over estimates the holdup and ensures that our determination sets an upper bound on the content of fissile material.

We take further steps to ensure the reported value represents an upper bound on the fissile material content. In the Pad 19 MRS facility and in the SRNL facility we obtain glovebox measurements from both sides. Therefore both walls and the floor are observed with overlapping fields of view that are overcalculated by the assumption that all activity is taken as originating from the opposite wall. The measured values and lower limits of detection for each of ${ }^{237} \mathrm{~Np},{ }^{238} \mathrm{Pu},{ }^{239} \mathrm{Pu}$, and ${ }^{241} \mathrm{Pu}$ are calculated for each acquisition. The measured values and limits of detection are then summed for each species and then doubled to report an upper level of content. For thorough conservatism, the limits of detection are not added in quadrature as is accepted practice, but rather are treated as pseudo measured values in the sum.

For the Pad 6 VE glovebox we do not obtain measurements from both sides of the glovebox. Instead we obtain the four measurements that we denote as positions 1 through 4 . We also obtain an oblique view measurement of the left corner of the glovebox and an additional view of the HEPA filter in the right 
WSRC-STI-2007-00127, Rev. 1

$5 / 4 / 2007$

5 of 21

corner. These acquisitions are shown schematically in Figure 4. These six acquisitions adequately overlap the floor and front face of the glovebox so that our summed and doubled reported values clearly represent an upper bound of the TRU content of the facility.

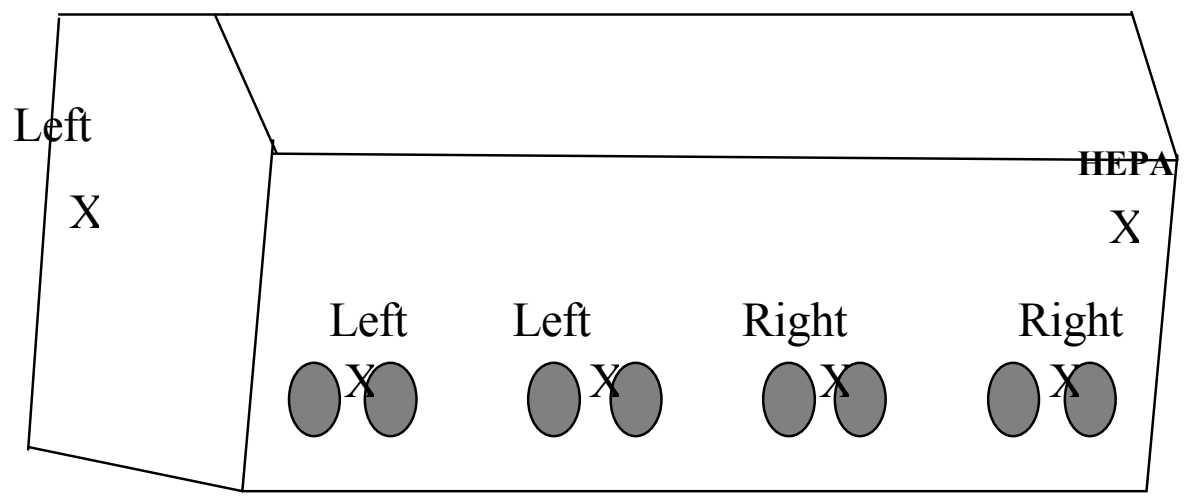

Figure 4. Pad 6 glovebox schematic view of assay points (Six positions assayed - designated by X).

The HEPA filter measurements in the Pad 19 MRS and SRNL facilities do not represent overlapping fields of view. As shown in Figures 1 and 2 the HEPA filters are viewed individually with the $\gamma$-ray detector, and the measured contents or minimum detectable activity (MDA) are calculated accurately without administrative conservatism. The transmission correction factor and geometry factor are determined by the ISOTOPIC code using the HEPA filter calculation configuration. As above with the glovebox acquisitions, the measured values and MDA's are summed and doubled. The MDA's are once again treated as pseudo measured values. The overall reported values clearly represent an upper bound of the fissile material content.

\section{EXPERIMENTAL}

Photographs of the three facilities are shown in Figures $5-7$. Because of the very restrictive ergonomic constraints, each requires a special detector support device built especially for that facility. For the Pad 19 MRS the detector support parameters were dictated by the narrow catwalks and confined detector space coupled with the requirement of assaying the glovebox HEPA filters above the two gloveboxes. The ingenious support system for the Pad 19 MRS is easily disassembled without tools into seven component parts. A photo of this device is shown in Figure 8. For the SRNL facility, the glovebox and HEPA filter orientations are very similar to those of the MRS, but the personnel walkways are wider. We were able to design a much more simple and user friendly hydraulic adjustable support table that is shown in Figure 9. The Pad 6 VE glovebox requires only a simple but heavy hydraulic lift support that does not need to be elevated above the glovebox. The HEPA filter system on Pad 6 is assayed by viewing into the glovebox as indicated in Figure 4. 
WSRC-STI-2007-00127, Rev. 1 $5 / 4 / 2007$

6 of 21

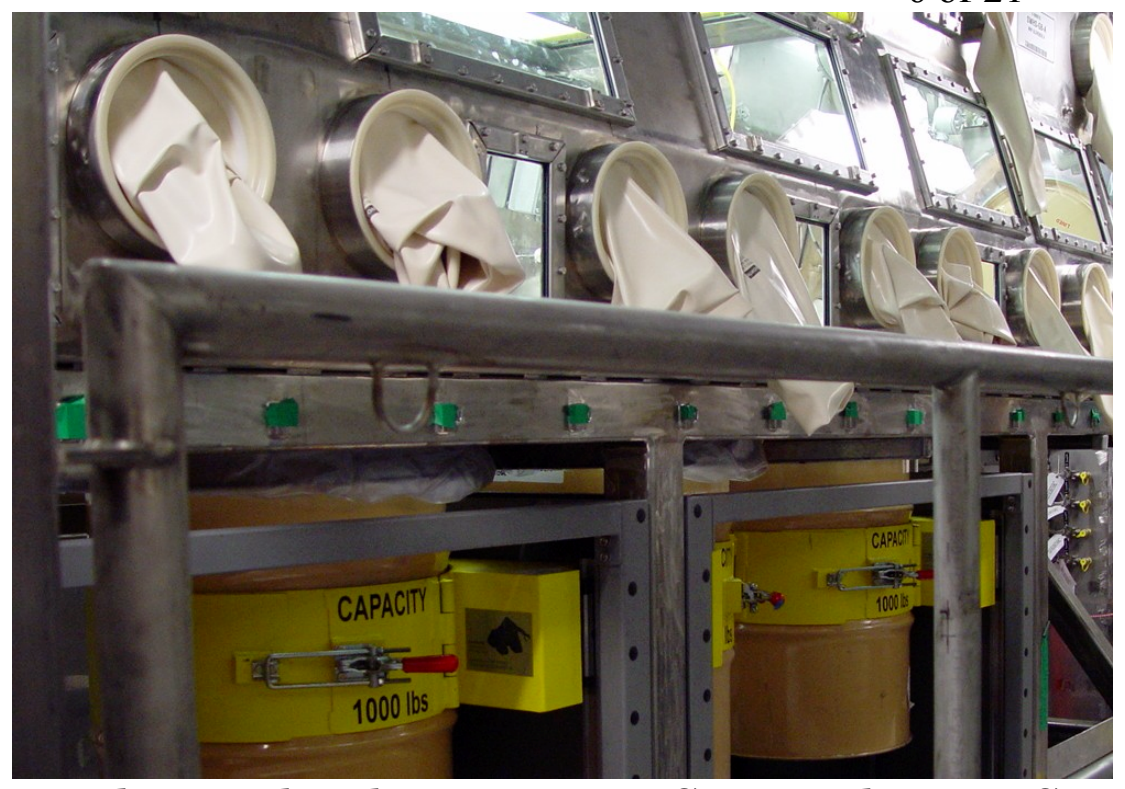

Figure 5. Pad 6 VE glovebox train at a Savannah River Site facility.

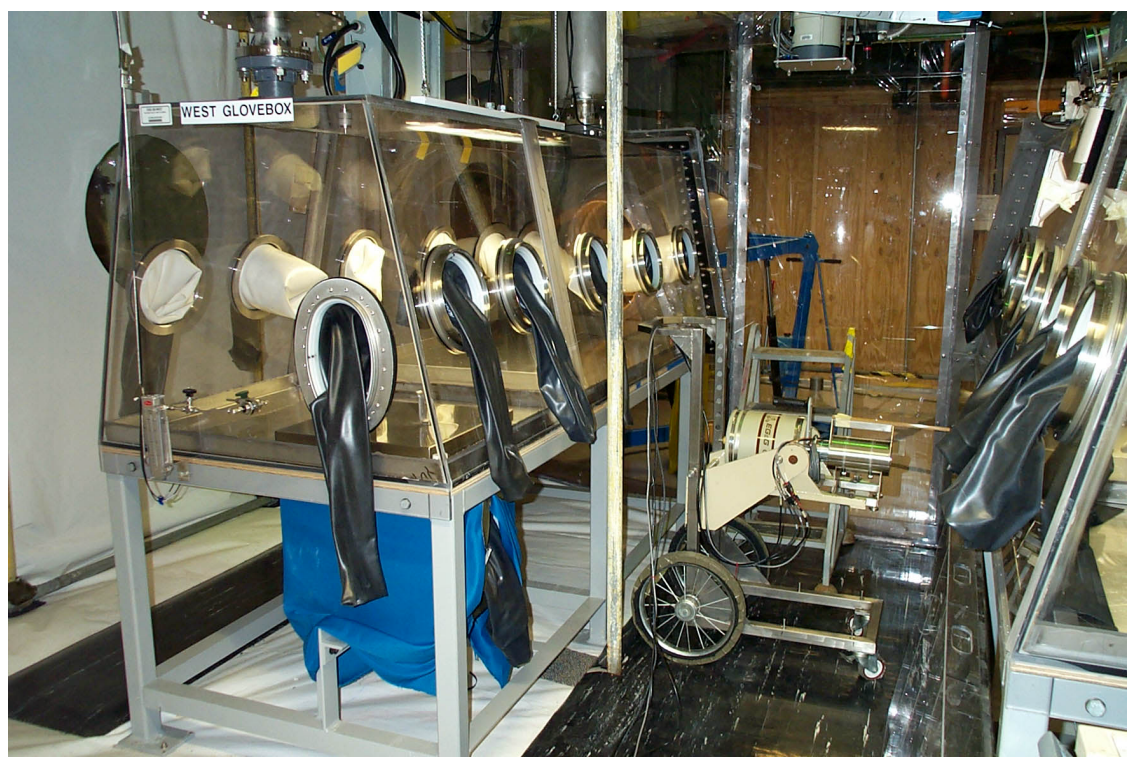

Figure 6. SRNL glovebox facility showing both gloveboxes and the center aisle between them. 
WSRC-STI-2007-00127, Rev. 1

7 of 21

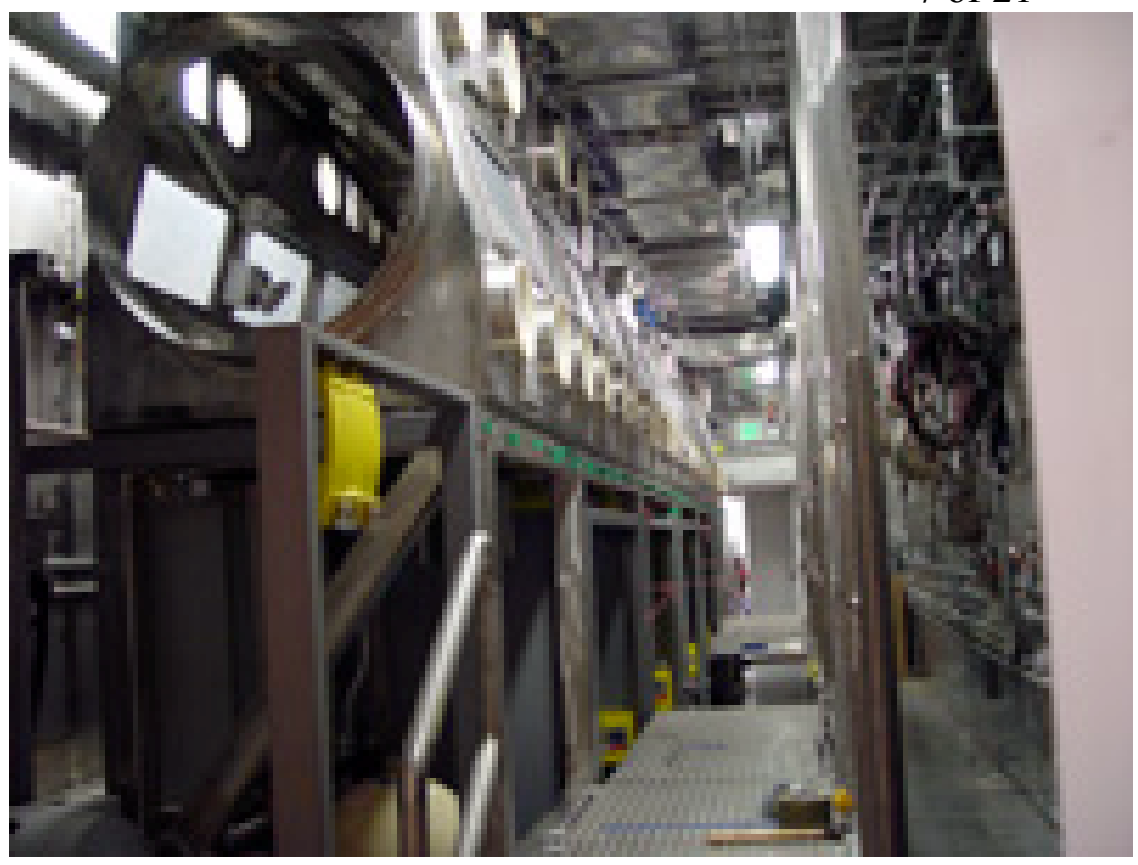

Figure 7. Pad 19 MRS Glovebox facility.

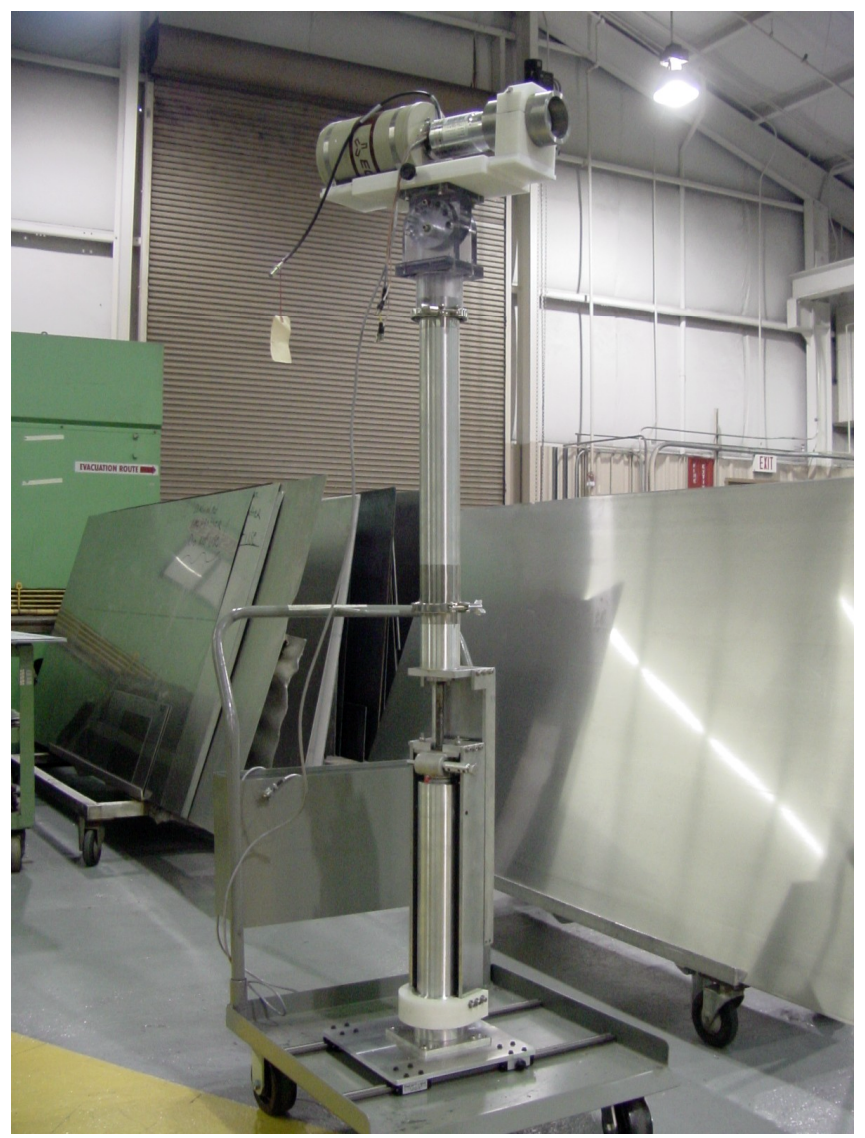

Figure 8. Pad 19 Assay support system showing the detector on the removable extender. The detector can tilt $\pm 180^{\circ}$ as well as rotate in a full circle, and the support system can translate in three dimensions. 


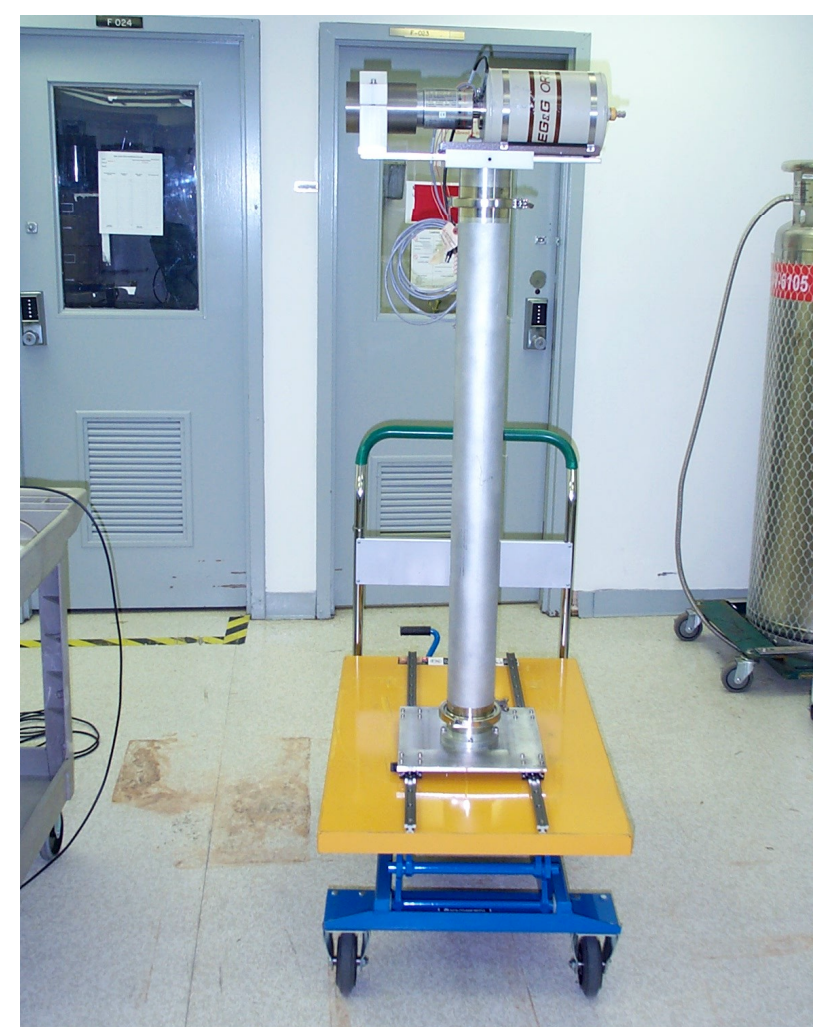

Figure 9. Photo of the SRNL support table showing the detector on the removable extender. The detector can rotate a full circle and translate in three dimensions.

The three facilities use different dedicated detectors for the acquisitions. Each detector has been calibrated in the point source configuration using one of two sources of mixed activity. ${ }^{8,9}$ The efficiency calibration of high purity germanium detectors generally follow one of two separate approaches, both of which are approved by the American National Standards Institute (Ref. 10). The approach used by ISOTOPIC (Ref. 6) involves calibration of the full-energy peak efficiency as a function of $\gamma$-ray energy. In the other approach, standardization coefficients are determined by directly comparing results to a standard source of the same radionuclide. We have calibrated a fourth portable HPGe detector as backup. While each system is intended to have its own dedicated detector, all four are actually interchangeable on the support devices, and we have used this capability on a few necessary occasions.

The first efficiency calibration approach is more general because it enables quantification of all radionuclides that are observed in a $\gamma$-ray spectrum rather than limiting the analysis to only one or two calibrated radionuclides. In this method, radionuclides having known $\gamma$-ray emission rates and covering a wide range of $\gamma$-ray energies are measured in a known geometry. A least squares fit of a polynomial of the natural logarithms of the observed efficiencies to the natural logarithms of corresponding $\gamma$-ray energies is used to describe a germanium spectrometer's efficiency behavior over the energy range. Activities of other radionuclides measured in the same geometry can then be determined using known $\gamma$ ray emission probabilities. Additional corrections are required to account for differences between the observed and the calibrated geometries, and in attenuation between the calibration standard and the object being measured. The latter corrections are treated by ISOTOPIC. We calibrated the four 
WSRC-STI-2007-00127, Rev. 1

$5 / 4 / 2007$

9 of 21

detectors used in this work in the point source geometry from a distance of twelve inches. ${ }^{3}$ Detection efficiencies in the point source configuration at twelve inches are shown in tabular form for each detector in reference 3. Typical efficiencies range from $6 \times 10^{-4}$ to $2 \times 10^{-3}$ at about $150-\mathrm{keV}$ down to $4 \times 10^{-5}$ to $10^{-4}$ near $1800 \mathrm{keV}$. An example efficiency curve is shown in Figure 10.

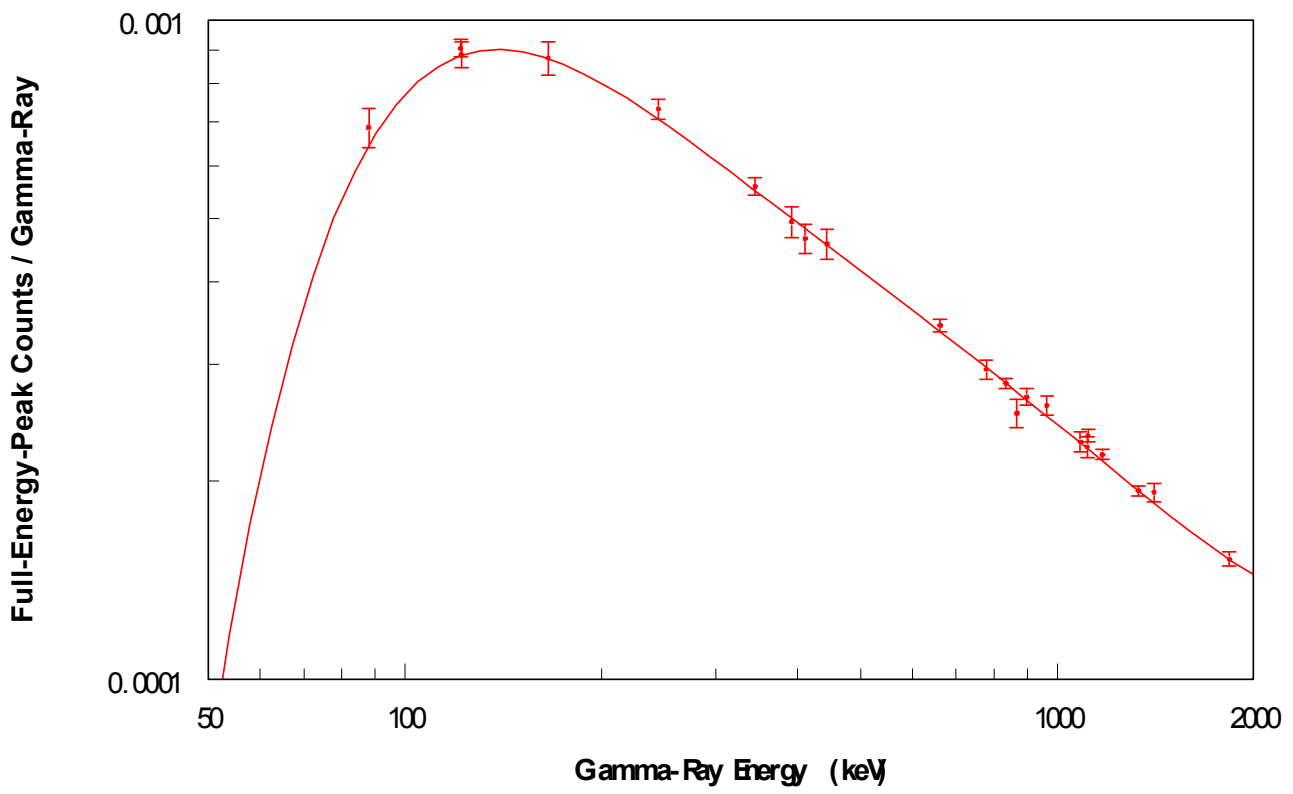

Figure 10. Gamma-ray efficiency versus energy for standard sources at a detector-to-source distance of 12 inches for detector S/N 36-TP210858B.

\section{Glovebox Corrections}

For all three facilities the glovebox acquisitions and corrections calculated by the code ISOTOPIC are fairly straightforward. The configuration is greatly simplified by our deliberate intention to overestimate the contents of each species. For all three facilities we orient the detector 10 inches away from the near wall and ten inches above the glovebox floor. In the modeling we assume that all observed activity comes from the opposite wall of the glovebox. Thus for the portion of activity that actually comes from the glovebox floor, the acquisition distance is overestimated, and the contents are thus over-calculated. The calculated content is guaranteed to be positively biased. The opposite glovebox wall in the MRS Pad 19 case is 42 inches away. For the VE Pad 6 it is 36 inches away, and for the SRNL case it is 38 inches away. Typical geometry correction factors to convert from a twelve-inch point source configuration to the relevant area source configuration are $\mathrm{Cf}_{\text {geo }}(\mathrm{Pad} 19)=26.78, \mathrm{Cf}_{\text {geo }}(\mathrm{Pad} 6)=10.95$, and $\mathrm{Cf}_{\text {geo }}(\mathrm{SRNL})=$ 19.12. That is, for a $\mu \mathrm{Ci}$ of activity counted in the point source at twelve inches, the detector would register 26.78 times as many counts as it would for that same $\mu \mathrm{Ci}$ of activity spread over a finite area source 42 inches away. The correction factor of 26.78 is purely a geometric one that is independent of photon energy.

Continuing to use the Pad 19 configuration as the example, note that the acquisition distance of 42 inches is 3.5 times the calibration point source acquisition distance of twelve inches. The simple point source configuration correction factor would be $(3.5)^{2}=12.25$. Spreading the activity uniformly over the finite area source further decreases the detector's geometric efficiency. It is in calculating that difference in the 
WSRC-STI-2007-00127, Rev. 1

$5 / 4 / 2007$

10 of 21

geometric correction factor where the code ISOTOPIC is especially valuable. These geometry correction factors also include the detector collimation in the geometric field of view. Each of our three detectors has it's own unique collimator that is included as part of the input into the code ISOTOPIC.

The code ISOTOPIC also calculates container and matrix absorption correction factors that are energy dependent. For the glovebox acquisitions, $\gamma$-rays from activity inside the glovebox have to transmit through only the glovebox wall of 0.25 inches of density $1.2 \mathrm{~g} / \mathrm{cc}$ plexiglass in order to reach the detector. Container correction factors are typically 1.13 at $152-\mathrm{keV}$ and near 1.0 at $414-\mathrm{keV}$. The matrix correction factor assumes the $\gamma$-rays must traverse 0.1 inch of $0.3 \mathrm{~g} / \mathrm{cc}$ density particles of sample. Sample (matrix) self absorption correction factors are typically near 1.01 at $153 \mathrm{keV}$ and near 1.004 at $414 \mathrm{keV}$. The overall correction is the product of the geometrical correction factor, the energydependent matrix factor, and the energy-dependent container factor. A typical ISOTOPIC glovebox configuration is shown in Figure 11.

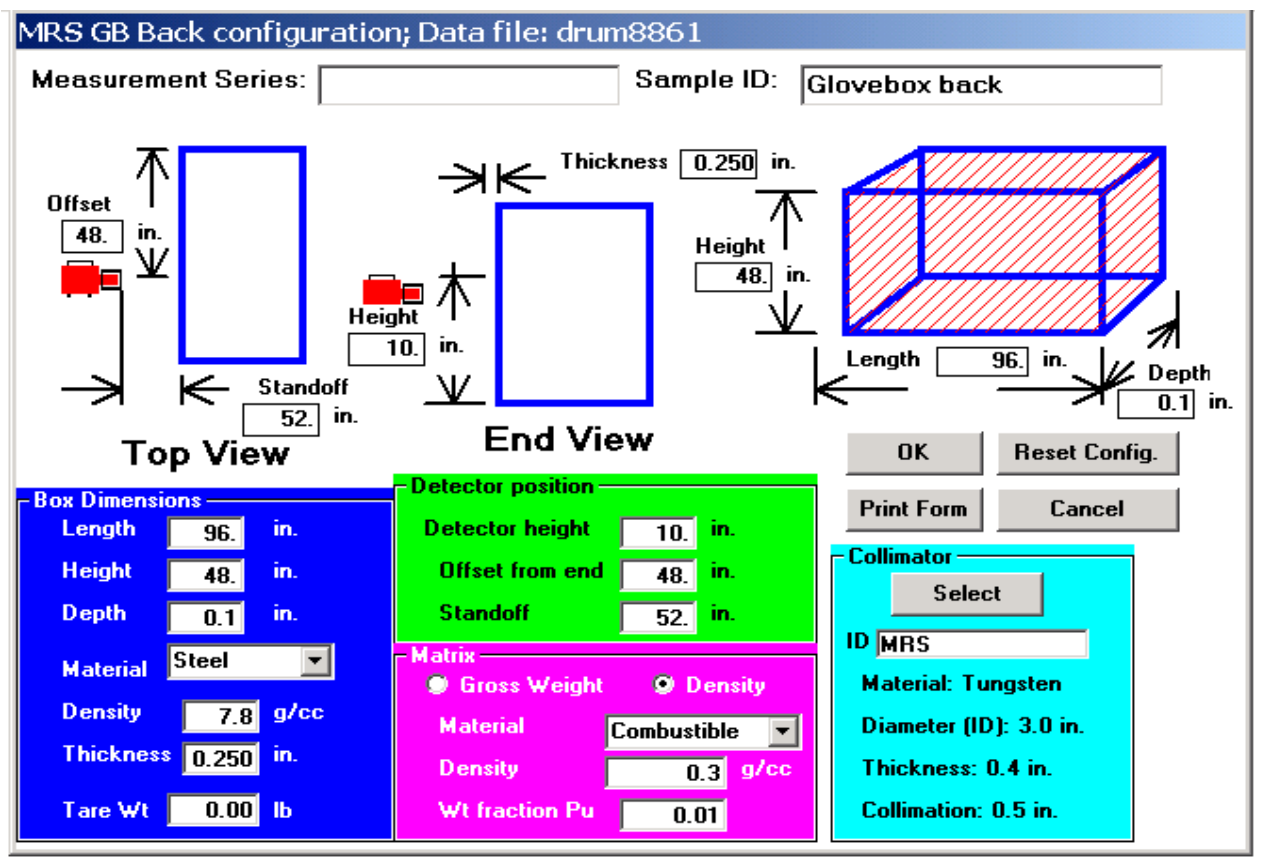

Figure 11. Isotopic glovebox assay configuration.

\section{HEPA Filter Corrections}

The HEPA filter geometry is more complex because the detector is viewing a cylindrical surface that has both an internal matrix and a stainless steel shell around the filter. In the filter we assume all of the material is retained as mass-less particles with no self-absorption. In the case of the HEPA filters we use a 7.5-inch standoff, which means the detector face is approximately twelve inches from the cylinder axis. The SRNL HEPA is different from the Pad 6 and Pad 19 filters. The cylindrical shell container is also different for the two types of filters.

The geometry correction factor for the Pad 19 acquisitions is $\mathrm{Cf}_{\text {geo }}(\mathrm{Pad} 19$ filter $)=1.08$. This represents an integrated average where part of the cylindrical shell filter is closer than twelve inches from the detector face and part is more than twelve inches away. The integrated average also includes the vertical profile of the cylindrical shell. The ISOTOPIC code performs this calculation assuming the TRU residue 
WSRC-STI-2007-00127, Rev. 1

$5 / 4 / 2007$

11 of 21

is distributed uniformly throughout the HEPA filter in the form of mass-less particles. The matrix correction factor assumes the $\gamma$-rays must traverse the HEPA filter material of diameter nine inches and density $0.3 \mathrm{~g} / \mathrm{cc}$. Matrix self-absorption correction factors are typically near 1.5 at $153 \mathrm{keV}$ and near 1.3 at $414 \mathrm{keV}$. For the container the code calculates transmission factors passing through $3 / 8$-inches of nine-inch diameter stainless steel. Pad 19 HEPA filter container transmission correction factors are typically $(2.9 \pm 0.7)$ at $153 \mathrm{keV}$ and $(1.7 \pm 0.2)$ at $414 \mathrm{keV}$.

The geometry correction factor for the SRNL acquisitions is $\mathrm{Cf}_{\text {geo }}(\mathrm{SRNL}$ filter $)=1.19$. The ISOTOPIC code performs this calculation assuming the TRU residue is distributed uniformly throughout the HEPA filter in the form of mass-less particles. The matrix correction factor assumes the $\gamma$-rays must traverse the HEPA filter material of diameter twelve inches and density $0.3 \mathrm{~g} / \mathrm{cc}$. Matrix self-absorption correction factors are typically $(1.8 \pm 0.8)$ at $153 \mathrm{keV}$ and $(1.4 \pm 0.4)$ at $414 \mathrm{keV}$. For the container the code calculates transmission factors passing through $1 / 8$-inch of twelve-inch diameter stainless steel. SRNL HEPA filter container transmission correction factors are typically $(1.4 \pm 0.2)$ at $153 \mathrm{keV}$ and (1.2 \pm 0.2$)$ at $414 \mathrm{keV}$.

The Pad 6 HEPA filter is a simple rectangle situated on the back of the glovebox wall. It is assayed in the same acquisition configuration as all of the glovebox wall acquisitions. For the Pad 6 filter we do not distinguish between it and the other five glovebox acquisitions. The code ISOTOPIC uses the same set of calculations for all six acquisitions. For all three of the facilities the bulk of the measured activity has always been observed in the HEPA filters. A typical HEPA filter acquisition configuration is shown in Figure 12.

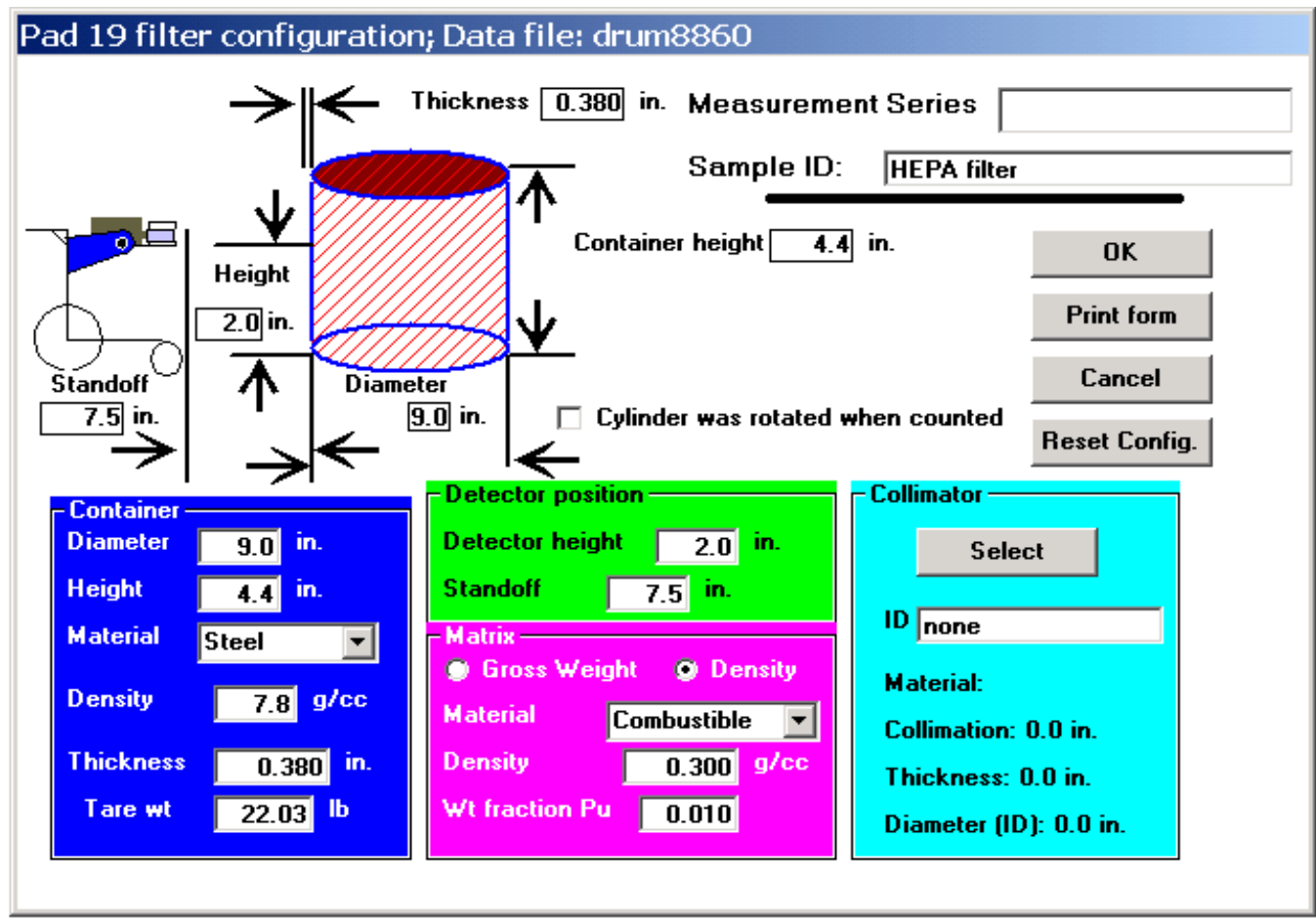

Figure 12. Isotopic HEPA filter acquisition configuration. 
WSRC-STI-2007-00127, Rev. 1

$5 / 4 / 2007$

12 of 21

\section{CALCULATIONS}

For each acquisition the calculation converts detected events to measured mass from the fit of the $\gamma$-ray spectrum using peak area under a defined region of interest that includes the transition energy of interest. From the acquisition time the analysis code ${ }^{(11,12)}$ determines counts/sec for each peak observed. We have generally used the Canberra Genie2000 system of reference 11 for these acquisitions, but the Ortec GammaVision system of reference 12 is equally powerful, and we have used it interchangeably in multiple holdup determination. Both systems contain an auto peak search that determines peak area for each photon transition energy.

The Genie2000 analysis routine divides by the detector efficiency curve peak by peak and applies the TRU and long-lived fission product peak library to recognize and associate the observed $\gamma$-ray peaks with individual radionuclide species. It then applies known decay branching ratios to determine decay rate for the species for each $\gamma$-ray transition observed. This portion of the calculation is defined by equation (1).

$$
\left.d p s\left({ }^{239} P u, 414\right)=\text { counts } E_{i} / t\left\{\text { branch }\left(\text { species }, E_{i}\right)\right]\left[\text { Eff }\left(E_{i}\right)\right]\right\},
$$

where $t$ is the acquisition count time in seconds, branch is the $\gamma$-ray branching ratio for the species, and Eff is the predetermined twelve-inch point source detector efficiency at energy $\mathrm{E}_{\mathrm{i}}$. A typical example for the species ${ }^{239} \mathrm{Pu}$ and with the 414-keV branch is shown in equation (2).

$$
\operatorname{dps}\left({ }^{239} \mathrm{Pu}, 414\right)=3942 / 600\{[0.0000151][0.00048]\}=9.06 \times 10^{8} \mathrm{dps} .
$$

The analysis code makes a similar calculation of ${ }^{239} \mathrm{Pu}$ decay rate for each of its $\gamma$-ray transitions observed in the spectrum. It also performs a calculation of minimum detection limit for those transition energies not observed.

The ISOTOPIC code uses the results of (2) and applies the geometric, container, and (matrix or sample) correction factors to determine a corrected decay rate for the species that is energy dependent. For equation (2) and using an SRNL HEPA filter example, the ISOTOPIC code would yield in a typical example

$$
\begin{array}{llll}
\text { Corrected } \operatorname{dps}\left({ }^{239} \mathrm{Pu}, 414\right) & = & (\text { measured dps })\left(\mathrm{Cf}_{\text {geo }}\right)\left(\mathrm{Cf}_{\text {container }}\right)\left(\mathrm{Cf}_{\text {matrix }}\right) . \\
\text { Corrected } \operatorname{dps}\left({ }^{239} \mathrm{Pu}, 414\right) & = & 9.06 \times 10^{8}(1.19)(1.206)(1.437)= & 1.87 \times 10^{9} \mathrm{dps}
\end{array}
$$

From each result in (3) the code ISOTOPIC applies a least squares fit over all observed $\gamma$-ray energies for ${ }^{239} \mathrm{Pu}$ to determine a best-fit result for detected ${ }^{239} \mathrm{Pu}$ content. The code applies this technique for each TRU species in its library and converts from decays/sec to measured mass using the known specific activity for each species. A least squares measured value of $1.87 \times 10^{9} \mathrm{dps}$ for ${ }^{239} \mathrm{Pu}$ would yield a measured mass of

$$
\begin{array}{lll}
\operatorname{mass}{ }^{239} \mathrm{Pu} & =(\mathrm{dps}) /[(\mathrm{dps} / \mathrm{Ci})(\text { specific activity })], \text { and } \\
\operatorname{mass}{ }^{239} \mathrm{Pu} & =\left(1.87 \times 10^{9} \mathrm{dps}\right) /\left(3.7 \times 10^{10} \mathrm{dps} / \mathrm{Ci}\right)(0.06204 \mathrm{Ci} / \mathrm{g})=0.814 \mathrm{~g} .
\end{array}
$$

For the SRNL facility ${ }^{243} \mathrm{Cm}$ and ${ }^{244} \mathrm{Cm}$ generally appear in the $\gamma$-ray spectra. Since the primary transition for ${ }^{244} \mathrm{Cm}$ and for ${ }^{238} \mathrm{Pu}$ are at the same energy of $153-\mathrm{keV}$, we report values or upper limits of content for both species based on that single transition. The ${ }^{243} \mathrm{Cm}$ content is reported assuming radioactive equilibrium with the daughter ${ }^{239} \mathrm{~Np}$, for which we observe several $\gamma$-rays. Likewise ${ }^{237} \mathrm{~Np}$ is reported in all facilities from the ${ }^{237} \mathrm{~Np} /{ }^{233} \mathrm{~Pa}$ radioactive equilibrium. The measured results and limits of detection for 
WSRC-STI-2007-00127, Rev. 1

$5 / 4 / 2007$

13 of 21

one example Pad 19 and two example SRNL assays are tabulated in the Appendix of this report. Also an example Pad 6 measured result appears in the Appendix.

\section{RESULTS and DISCUSSION}

All of the glovebox fields of view in each of the Pad 6, Pad 19, and SRNL measurements have overlapping segments. Thus for these overlapping portions we are double-counting the activity. For the Pad 19 and SRNL gloveboxes we observe from both sides of the glovebox. Therefore we are further double counting a portion of the front wall and a portion of the glovebox floor. In addition, we deliberately over-state the acquisition distances. For a further margin of conservation, we double the summed result. Therefore the reported contents of the Pad 19 and SRNL gloveboxes are likely about a factor of ten larger than the true values. We believe we have modeled the HEPA filter measurements accurately, so the only margin of conservation included is the doubling step.

The reported values for the Pad 6 Visual Examination facility and for the Pad 19 Modular Remediation System are in every case well below the facility operating limits. For these two facilities the reported values do not challenge the assumption of $10 \%$ holdup even including the very large positive conservatism. For the Pad 19 MRS the sustained rapid throughput of drums meant the facility quickly approached the administrative boundaries, and so for much of 2006 assays were requested on a frequent weekly or bi-weekly basis. The assay results for Pad 19 and for Pad 6 always returned the facility to a condition with comfortable "freeboard" in the fissile material content. Figure 13 represents the Pad 6 VE measurements compared to the administrative boundary for the first fourteen assays over nearly three years. The reported values of ${ }^{239} \mathrm{Pu}$ content in the SRNL facility were on successive measurements 12.4 g, $13.6 \mathrm{~g}, 31.3 \mathrm{~g}, 19.5 \mathrm{~g}, 27.8 \mathrm{~g}, 27.1 \mathrm{~g}$, and $19.9 \mathrm{~g}$. These results kept the SRNL facility near its operating limit.

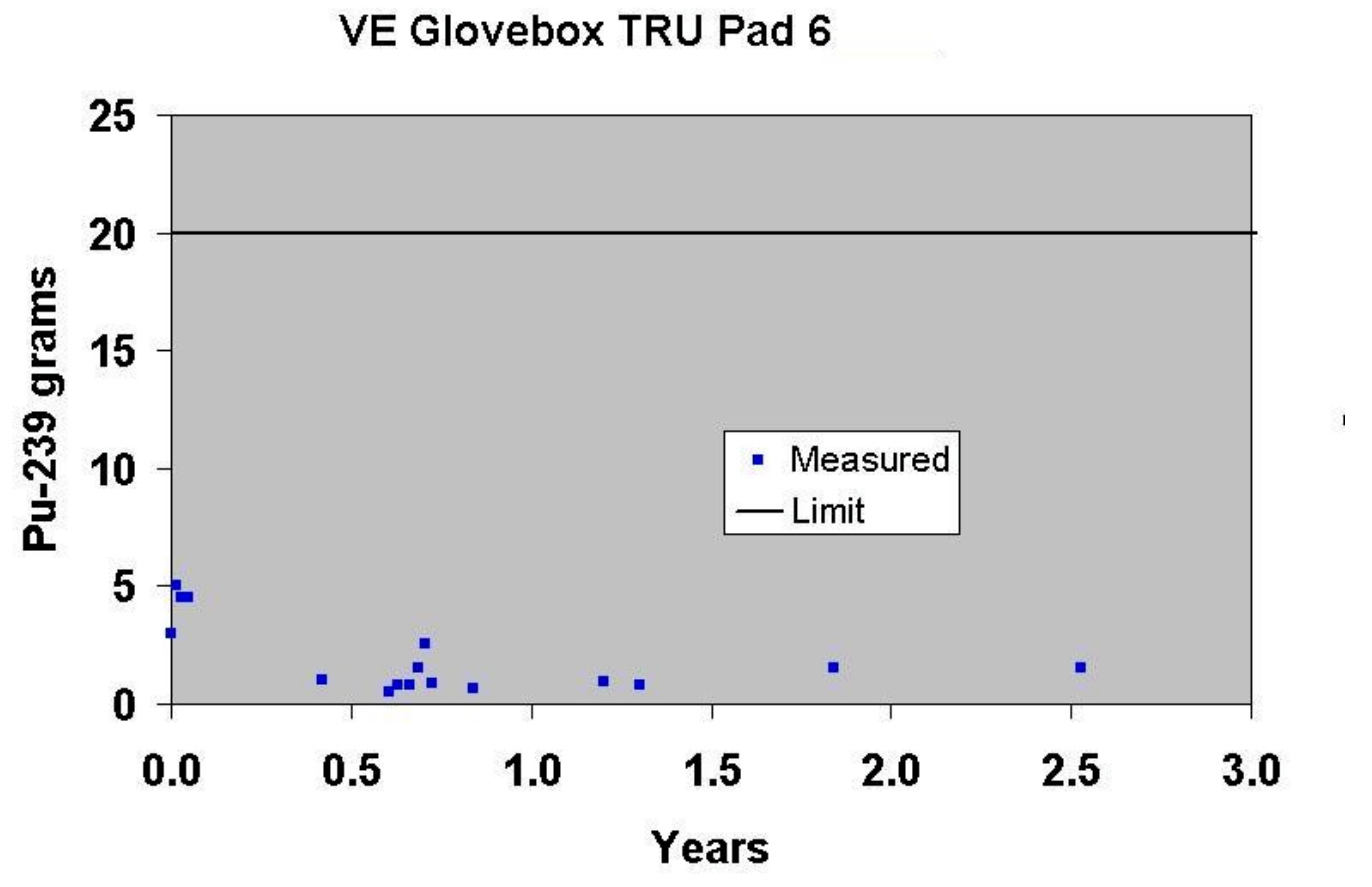

Figure 13. Pad 6 VE measurements compared to the administrative boundary for the first fourteen assays over nearly three years. 
WSRC-STI-2007-00127, Rev. 1

$5 / 4 / 2007$

14 of 21

The SRNL repackaging glovebox facility completed its mission in November 2006. On 30 November we obtained a final assay after reprocessing, and on 7 January 2007 we obtained a closure assay after a thorough decontamination of the two gloveboxes. Note the two HEPA filters were not decontaminated. It is interesting to compare the measured values obtained between the November 2006 assay and the January 2007 assay. Clearly all values contain near 100\% uncertainty, but it seemed useful to observe whether the measured contents correlate with decontamination.

Since the gloveboxes were decontaminated between the last two measurements it is reasonable to assume that the measured values should all drop. Referring to the two appropriate Tables in the Appendix note the reported ${ }^{238} \mathrm{Pu}$ values are 0.0734 (January) and 0.0913 (November), and the reported ${ }^{239} \mathrm{Pu}$ contents are 19.9 (January) and 27.1 (November). Clearly the ${ }^{241} \mathrm{Pu}$ reported values should scale similarly.

Note in the east glovebox assay of January we obtained a point by point reduction of measured ${ }^{239} \mathrm{Pu}$ content of about $50 \%$ relative to the November assay. Similarly the point by point comparison of the measured ${ }^{238} \mathrm{Pu}$ values yields a $20 \%$ reduction. That's fairly good statistics, and demonstrates excellent endorsement of our stated measured values. For ${ }^{241} \mathrm{Pu}$, the one single measured value reported in January (GBA-E-4) shows a 45\% reduction compared to that measured value in November. Wow! That is outstanding! Note also the limits of content reported in glovebox W in January agree extremely well with the same limits of content reported in November.

Making the same point by point comparison for the eight measured contents of $\mathrm{Np}-237$ in the two gloveboxes demonstrates that we observed a $37 \%$ reduction of ${ }^{237} \mathrm{~Np}$ content after decontaminating. The same comparison for the three measured values of ${ }^{243} \mathrm{Cm}$ content obtained in January 2007 demonstrates a $34 \%$ reduction of observed ${ }^{243} \mathrm{Cm}$. Finally note a point by point comparison between each of the individual HEPA filter measurements (both east and west) are extremely consistent for all of the six species reported. This again lends a lot of credibility to the quality of our measurements. The HEPA filters received no decontamination, so the values should agree well. From November to January the measured contents of both HEPA filters went up. Possibly in both cases we were acquiring data slightly closer to a local hot spot in January. Or we can rationalize that the filters were still collecting activity during the decontamination.

The HEPA filters are modeled to accurately determine their TRU content. That is, we do not deliberately double-count them, nor do we obtain overlapping views. Therefore it would be very instructive to somehow gain a measurement that confirms the accuracy of the HEPA filter assays. We believe that an assay of the isolated HEPA filters would yield an excellent confirmation of our original modeling of them. Such a confirmation would be especially valuable to benchmark the technical merit of all of the assays in all three facilities.

After the HEPA filters were removed from the glovebox facility they were placed in separate 55-gallon drums and assayed using the SRNL $Q^{2}$ drum counter. The $Q^{2}$ is a three-segment vertical passive $\gamma$-ray scanner that is described in reference 13. It performs a transmission correction based upon the mass of the drum and assuming a uniform known composition. The masses of the drums were $56.5 \mathrm{~kg}$ (net 29.5) and $58.0 \mathrm{~kg}$ (net 31.0), which yielded matrix transmission correction factors near 1.1 (matrix $\rho=0.15$ $\mathrm{g} / \mathrm{cc}$ ) at the 414-keV $\gamma$-ray from ${ }^{239} \mathrm{Pu}$ decay. ${ }^{14}$ The matrix-only correction factor (input matrix $\rho=0.30$ $\mathrm{g} / \mathrm{cc}$ ) for the in-situ ISOTOPIC models were approximately 1.44. The measured quantities in the two HEPA filters from the $\mathrm{Q}^{2}$ acquisitions are listed in Table 1, where we compare them with the final January 2007 in-situ measurements. Note that using the same input value of matrix $\rho=0.30 \mathrm{~g} / \mathrm{cc}$ would have yielded a $\mathrm{Q}^{2}$ matrix transmission correction factor of 1.2, in better agreement with the value calculated by our ISOTOPIC model. We discuss the results below. 
WSRC-STI-2007-00127, Rev. 1

$5 / 4 / 2007$

15 of 21

We also performed $\gamma$-ray assays of both drums lying on their sides so that we were observing down the symmetry axis of the two isolated HEPA filters. For this comparison assay we had both a unique acquisition configuration and a detector different from the one used in the in-situ acquisitions of the HEPA filters. So, while the technique of analysis is still $\gamma$-PHA, the configuration and detector are both unique and independent of the in-situ analyses. For both drums we observed down the 33-inch symmetry axis of the drum and assumed the detector was approximately centered on the symmetry axis of the HEPA filter. We used a standoff distance of 47 inches in one case and of 53 inches for the other. The code ISOTOPIC does not allow us to model a cylinder with the detector looking down the symmetry axis, so we used a rectangular prism with 22-inch sides and a length of 33 inches in the model. Our geometry factors in this configuration were 20.7 for the 47 -inch standoff and 25.3 for the 53 -inch standoff, which are both considerably larger than the in-situ geometry factors of 1.2. We compare the measured values obtained in Table 2, which is presented in the same format as Table 1. Our matrix-only correction factors for matrix $\rho=0.30 \mathrm{~g} / \mathrm{cc}$ were 1.54 in this configuration.

Table 1. Comparison of measured content $(\mu \mathrm{Ci})$ of the final in-situ assay of the SRNL HEPA filters to the measured values off-line using the SRNL $Q^{2}$ instrument.

\begin{tabular}{|c|c|c|c|c|c|}
\hline Species & HEPA E & $\mathbf{Q}^{2}$ & species & HEPA W & $\mathbf{Q}^{2}$ \\
\hline${ }^{238} \mathrm{Pu}$ & $\mathbf{1 . 3 1 E}+\mathbf{0 5}$ & $6.54 \mathrm{E} 4^{*}$ & ${ }^{238} \mathrm{Pu}$ & $\mathbf{2 . 6 2 E}+\mathbf{0 5}$ & $1.48 \mathrm{E} 5^{*}$ \\
\hline${ }^{239} \mathrm{Pu}$ & $\mathbf{1 . 6 2 E}+\mathbf{0 5}$ & $1.20 \mathrm{E}+05$ & ${ }^{239} \mathrm{Pu}$ & $\mathbf{1 . 7 1 E}+\mathbf{0 5}$ & $1.09 \mathrm{E}+05$ \\
\hline${ }^{241} \mathrm{Pu}$ & $\mathbf{6 . 6 8 E}+\mathbf{0 5}$ & $3.84 \mathrm{E}+05$ & ${ }^{241} \mathrm{Pu}$ & $\mathbf{7 . 1 9 E}+\mathbf{0 5}$ & $3.72 \mathrm{E}+05$ \\
\hline${ }^{237} \mathrm{~Np}$ & $\mathbf{3 . 2 7 E}+\mathbf{0 1}$ & 28.3 & ${ }^{237} \mathrm{~Np}$ & $\mathbf{2 . 9 9 E}+\mathbf{0 1}$ & 20.6 \\
\hline${ }^{243} \mathrm{Cm}$ & $\mathbf{2 . 8 9 E}+\mathbf{0 1}$ & $25.58 *$ & ${ }^{243} \mathrm{Cm}$ & $\mathbf{2 . 3 5 E}+\mathbf{0 1}$ & $17.2^{*}$ \\
\cline { 4 - 5 }${ }^{244} \mathrm{Cm}$ & $\mathbf{1 . 3 1 E}+\mathbf{0 5}$ & & ${ }^{244} \mathrm{Cm}$ & $\mathbf{2 . 6 2 E}+\mathbf{0 5}$ & \\
\hline${ }^{245} \mathrm{Cm}$ & $5.53 \mathrm{E}-01$ & & ${ }^{245} \mathrm{Cm}$ & $4.68 \mathrm{E}-01$ & \\
\hline${ }^{241} \mathrm{Am}$ & $\mathbf{3 . 1 1 E}+\mathbf{0 5}$ & $\mathbf{8 . 7 3 E}+\mathbf{0 3}$ & ${ }^{241} \mathrm{Am}$ & $2.92 \mathrm{E}+04$ & $6.48 \mathrm{E}+03$ \\
\hline
\end{tabular}

We believe the comparison in Table 1 between the $\mathrm{Q}^{2}$ measurements and the in-situ measurements is very favorable. Note the $\mathrm{Q}^{2}$ measurements in Table 1 do not report ${ }^{244} \mathrm{Cm}$. In our in-situ measurements we were not able to distinguish ${ }^{244} \mathrm{Cm}$ from ${ }^{238} \mathrm{Pu}$, so we reported measured contents where all of the 153$\mathrm{keV} \gamma$-ray activity was assigned separately to each. Thus our measured ${ }^{238} \mathrm{Pu}$ is approximately twice the $\mathrm{Q}^{2}$ measured ${ }^{238} \mathrm{Pu}$. Also in Table 1 we have summed the $\mathrm{Q}^{2}$ measured ${ }^{243} \mathrm{Cm}$ and ${ }^{239} \mathrm{~Np}$ values and represented all of that activity as ${ }^{243} \mathrm{Cm}$, since that is how we treated the in-situ measurements. Except for the ${ }^{241} \mathrm{Am}$ measurements, the data agree nicely. We reflect those two treatments in the modified ratio, where we compare the measured items species by species excluding ${ }^{241} \mathrm{Am}$. We believe the $\mathrm{Q}^{2}$ badly underestimates the ${ }^{241} \mathrm{Am}$ correction factor for the 59-keV $\gamma$-ray. Our in-situ measurements base the ${ }^{241} \mathrm{Am}$ content on higher energy $\gamma$-rays. The modified ratio values of $(1.28 \pm 0.29)$ and $(1.35 \pm 0.40)$ demonstrate the excellent agreement obtained between the two techniques.

The comparison in Table 2 between the in-situ and off-line measurements modeled by ISOTOPIC demonstrate extremely good agreement. The species by species comparisons yield direct ratios of $(0.82 \pm 0.37)$ and $(1.26 \pm 0.47)$. Excluding the ${ }^{245} \mathrm{Cm}$ values because all were measured upper limits of content with vastly different geometry factors yields direct ratios of $(0.92 \pm 0.28)$ and $(1.39 \pm 0.30)$. The 
WSRC-STI-2007-00127, Rev. 1 $5 / 4 / 2007$

16 of 21

measurements from Tables 1 and 2 are shown graphically in Figure 14. Wow, again! Even I can't believe the results came out that good.

Table 2. Comparison of measured content $(\mu \mathrm{Ci})$ of the final in-situ assay of the SRNL HEPA filters to the measured values off-line using detector in the cylindrical configuration as described in the text.

\begin{tabular}{|c|c|c|c|c|c|}
\hline Species & HEPA E & $\begin{array}{l}\text { HEPA E } \\
\text { in drum }\end{array}$ & Species & HEPA W & $\begin{array}{c}\text { HEPA W } \\
\text { in drum }\end{array}$ \\
\hline${ }^{238} \mathrm{Pu}$ & $1.31 \mathrm{E}+05$ & $1.24 \mathrm{E}+05$ & ${ }^{238} \mathrm{Pu}$ & $2.62 \mathrm{E}+05$ & $1.79 \mathrm{E}+05$ \\
\hline${ }^{239} \mathrm{Pu}$ & $1.62 \mathrm{E}+05$ & $2.00 \mathrm{E}+05$ & ${ }^{239} \mathrm{Pu}$ & $1.71 \mathrm{E}+05$ & $1.30 \mathrm{E}+05$ \\
\hline${ }^{241} \mathrm{Pu}$ & $6.68 E+05$ & $5.08 \mathrm{E}+05$ & ${ }^{241} \mathrm{Pu}$ & $7.19 E+05$ & $3.92 \mathrm{E}+05$ \\
\hline${ }^{237} \mathrm{~Np}$ & $3.27 \mathrm{E}+01$ & $3.17 \mathrm{E}+01$ & ${ }^{237} \mathrm{~Np}$ & $2.99 \mathrm{E}+01$ & $1.85 \mathrm{E}+01$ \\
\hline${ }^{243} \mathrm{Cm}$ & $2.89 \mathrm{E}+01$ & $3.84 \mathrm{E}+01$ & ${ }^{243} \mathrm{Cm}$ & $2.35 \mathrm{E}+01$ & $\mathrm{E}+01$ \\
\hline${ }^{244} \mathrm{Cm}$ & $1.31 \mathrm{E}+05$ & $1.28 \mathrm{E}+05$ & ${ }^{244} \mathrm{Cm}$ & $2.62 E+05$ & $1.79 E+05$ \\
\hline${ }^{245} \mathrm{Cm}$ & $1.62 \mathrm{E}+00$ & $1.00 \mathrm{E}+01$ & ${ }^{245} \mathrm{Cm}$ & $1.37 \mathrm{E}+00$ & $4.50 \mathrm{E}+00$ \\
\hline${ }^{241} \mathrm{Am}$ & $3.11 \mathrm{E}+05$ & $7.41 \mathrm{E}+05$ & ${ }^{241} \mathrm{Am}$ & $4.84 \mathrm{E}+05$ & $5.08 E+05$ \\
\hline \multicolumn{2}{|c|}{ Direct ratio } & $\mathbf{0 . 8 2} \pm \mathbf{0 . 3 7}$ & \multicolumn{2}{|c|}{ Direct ratio } & $1.26 \pm 0.47$ \\
\hline \multicolumn{2}{|c|}{ Excluding ${ }^{245} \mathrm{Cm}$} & $0.92 \pm 0.28$ & \multicolumn{2}{|c|}{ Excluding ${ }^{245} \mathrm{Cm}$} & $1.39 \pm 0.30$ \\
\hline
\end{tabular}
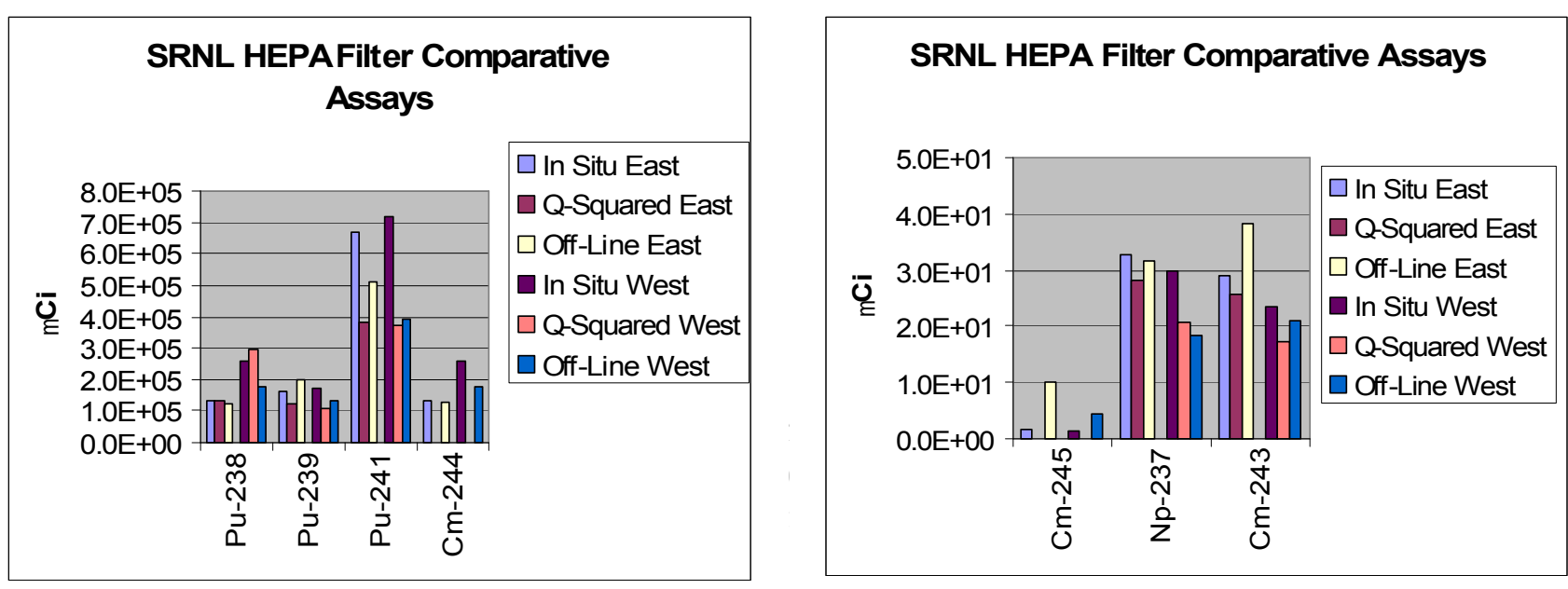

Figure 14. Comparison of measured contents (or MDA's) between the final in-situ assays, the $Q^{2}$ assays, and the off-line assays for the SRNL East and West glovebox HEPA filters. 
WSRC-STI-2007-00127, Rev. 1

$5 / 4 / 2007$

17 of 21

\section{Conclusion}

To date we have performed 37 measurements of TRU holdup in the three Site remediation glovebox facilities. These include twelve measurements performed in the difficult environment of the Pad 19 MRS glovebox, seven measurements in the SRNL facility, and eighteen measurements in the Pad 6 VE facility. In every case, using conservatism that over-calculates the TRU contents by up to a factor of ten, we were able to demonstrate that the facilities were operating within the prescribed administrative criticality limits. The SRNL facility has completed its mission, but the Pad 19 and Pad 6 facilities continue to operate.

Because of the success of our assay program, the Pad 19 and Pad 6 facilities have both been able to change the administrative procedures to implement less restrictive guidelines. For the years $2003-2006$ each facility assumed 10\% holdup of all processed TRU and required an assay when the projected holdup content reached prescribed limits. In early 2007 the assumed holdup was redefined to 5\%. This has extended the time between required assays and has thus increased processing up time.

Because the SRNL facility has completed its mission we have been able to perform experimental comparisons of measured content of the glovebox holdup and on the HEPA filters. A comparison of the glovebox holdup after final processing and after subsequent final decontamination has yielded a very favorable correlation of measured content species by species. That is, each of seven measured ${ }_{238,239,241} \mathrm{Pu}$, as well as ${ }^{241} \mathrm{Am}$ and ${ }^{243,244,245} \mathrm{Cm}$, have demonstrated consistent trending in the measured values. A further comparison of the holdup in the HEPA filters has demonstrated favorable trending in the species by species comparison.

We performed two especially valuable comparisons of the measured content in the SRNL HEPA filter units using the SRNL $Q^{2}$ assay facility and using off-line measurement of the HEPA filter contents in a separate acquisition configuration. These two comparisons that resulted in completely independent absorption factors and widely different geometry factors yielded very good agreement between measured contents. We believe this represents a very strong endorsement of the modeling of the systems and lends very good credibility to all of the measurements made in all three facilities. 
WSRC-STI-2007-00127, Rev. 1

$5 / 4 / 2007$

18 of 21

\section{References}

1. US Department of Energy Order 5820.2.A, 1988.

2. WSRC 1S, SRS Waste Acceptance Criteria Manual.

3. R. A. Sigg, V. R. Casella, and R. A. Dewberry, "Nondestructive Assay Efficiency Calibration of HPGe Detectors for the ORTEC 'Isotopic' Method”, WSRC-TR-2005-00431, September 2005.

4. V. R. Casella, “Gamma Assays Using ORTEC's ISOTOPIC Program (U) ADS 2460”, February 2006.

5. R. A. Sigg, V. R. Casella, and R. A. Dewberry, Holdup Measurements for Visual Examination Gloveboxes at the Savannah River Site", WSRC-MS-2006-00054, July 2006.

6. ISOTOPIC Version 2.0.6 Ametek/ ORTEC.

7. Casella et. al. "Task Technical and Quality Assurance Plan for Gamma Assays at the SRS Burial Ground”, WSRC-TR-2005-01914, December 2005.

8. M. Takaeva, Certificate of Calibration Analytics source 72091-147, January 2006.

9. M. Takaeva, Certificate of Calibration Analytics source 65993-147, April 2003.

10. American National Standard Calibration and Use of Germanium Spectrometers for the Measurement of Gamma-Ray Emission Rates of Radionuclides, ANSI N42.14-1999.

11. NDA2000 Integrated Gamma-Neutron Software 1.0, Canberra Industries, September 1999.

12. GammaVision Version 2.0.6 Ametek/ ORTEC.

13. Canberra Industries, “Q² Low Level Waste Assay System Operation Manual,” October 1994.

14. R. A. Dewberry and V. R. Casella, "Installation of NDA2000 Software into 363-1M Q2 Operation", WSRC-TR-2003-00351, September 2003. 
WSRC-STI-2007-00127, Rev. 1 $5 / 4 / 2007$

19 of 21

\section{APPENDIX}

Tables of Results for Pad 6 VE, for Pad 19 MRS, and for the SRNL Glovebox Holdup Acquisitions.

\begin{tabular}{|c|c|c|c|c|}
\hline \multicolumn{4}{|c|}{ Pad 19 MRS Glovebox Measurements } & \multirow{2}{*}{$\begin{array}{c}10 / 11 / 2006 \\
{ }^{237} \mathrm{~Np}\end{array}$} \\
\hline & ${ }^{238} \mathbf{P u}$ & ${ }^{239} \mathbf{P u}$ & ${ }^{241} \mathbf{P u}$ & \\
\hline GB-A \#1 & $1.88 \mathrm{E}-02$ & $1.26 \mathrm{E}+00$ & $5.53 \mathrm{E}-03$ & 4.59E-03 \\
\hline GB-A \#2 & $1.09 E-03$ & $5.26 \mathrm{E}-01$ & $3.94 \mathrm{E}-03$ & $7.97 \mathrm{E}-04$ \\
\hline GB-A \#3 & 2.12E-02 & $7.35 \mathrm{E}-01$ & $5.62 \mathrm{E}-03$ & $3.09 \mathrm{E}-03$ \\
\hline GB-A \#4 & $1.54 E-03$ & $5.34 \mathrm{E}-01$ & 4.34E-03 & $1.73 \mathrm{E}-04$ \\
\hline BG-A Total & $4.26 \mathrm{E}-02$ & $3.06 \mathrm{E}+00$ & $1.94 \mathrm{E}-02$ & $8.64 \mathrm{E}-03$ \\
\hline GB-B \#1 & $4.95 \mathrm{E}-03$ & $4.95 \mathrm{E}-01$ & $4.16 \mathrm{E}-03$ & 3.37E-03 \\
\hline GB-B \#2 & 6.98E-03 & 6.11E-01 & $5.84 \mathrm{E}-03$ & $2.09 E-02$ \\
\hline GB-B \#3 & $4.76 \mathrm{E}-03$ & $5.30 \mathrm{E}-01$ & $4.33 \mathrm{E}-03$ & 1.33E-03 \\
\hline GB-B \#4 & 3.37E-02 & 8.76E-01 & $6.48 \mathrm{E}-03$ & $2.58 \mathrm{E}-02$ \\
\hline BG-B Total & $5.04 \mathrm{E}-02$ & $2.51 \mathrm{E}+00$ & $2.08 \mathrm{E}-02$ & $5.14 \mathrm{E}-02$ \\
\hline HEPA \#A1 & $6.67 \mathrm{E}-03$ & $2.55 \mathrm{E}-01$ & $3.63 \mathrm{E}-04$ & $1.32 \mathrm{E}-03$ \\
\hline HEPA \#A2 & $8.66 \mathrm{E}-04$ & $2.68 \mathrm{E}-01$ & $3.70 \mathrm{E}-04$ & 1.27E-03 \\
\hline HEPA \#B1 & $7.19 \mathrm{E}-03$ & $1.94 \mathrm{E}-01$ & $3.77 \mathrm{E}-04$ & 1.22E-03 \\
\hline HEPA \#B2 & 9.43E-04 & $2.44 \mathrm{E}-01$ & $3.87 \mathrm{E}-04$ & 1.43E-03 \\
\hline HEPA \#WA & $4.01 \mathrm{E}-04$ & $2.30 \mathrm{E}-02$ & $3.40 \mathrm{E}-04$ & $8.99 \mathrm{E}-05$ \\
\hline HEPA \#WB & $4.03 \mathrm{E}-04$ & $2.55 \mathrm{E}-02$ & $3.38 \mathrm{E}-04$ & $9.75 \mathrm{E}-05$ \\
\hline Vacuum M & $1.04 \mathrm{E}-03$ & $8.03 \mathrm{E}-02$ & $8.88 \mathrm{E}-04$ & $1.36 \mathrm{E}-03$ \\
\hline Vacuum S & $4.03 \mathrm{E}-04$ & $8.62 \mathrm{E}-02$ & $8.41 \mathrm{E}-04$ & 8.32E-04 \\
\hline HEPA Total & $1.65 \mathrm{E}-02$ & $1.01 \mathrm{E}+00$ & $2.17 \mathrm{E}-03$ & $5.43 \mathrm{E}-03$ \\
\hline Total GB/HEPA & $1.09 \mathrm{E}-01$ & $6.58 \mathrm{E}+00$ & 4.24E-02 & $6.55 \mathrm{E}-02$ \\
\hline TOTAL X 2 & $2.19 \mathrm{E}-01$ & $1.32 \mathrm{E}+01$ & $8.48 \mathrm{E}-02$ & $1.31 \mathrm{E}-01$ \\
\hline & & & thore are & $\Delta \mathbf{s})$ \\
\hline
\end{tabular}

\begin{tabular}{|c|c|c|c|c|c|c|c|r|}
\hline \multicolumn{4}{|l|}{ Pad 6 VE Glovebox Measurements } & & & & & $\mathbf{1} / \mathbf{9} / \mathbf{2 0 0 7}$ \\
\hline & $\begin{array}{c}\text { Corner } \\
(\mathrm{g})\end{array}$ & $\begin{array}{c}\# 1 \\
(\mathrm{~g})\end{array}$ & $\begin{array}{c}\# 2 \\
(\mathrm{~g})\end{array}$ & $\begin{array}{c}\# 3 \\
(\mathrm{~g})\end{array}$ & $\begin{array}{c}\# 4 \\
(\mathrm{~g})\end{array}$ & $\begin{array}{c}\text { HEPA } \\
(\mathrm{g})\end{array}$ & $\begin{array}{c}\text { Total } \\
(\mathrm{g})\end{array}$ & $\begin{array}{c}\text { Reported } \\
(\mathrm{g})\end{array}$ \\
\hline${ }^{238} \mathrm{Pu}$ & $\mathbf{2 . 6 0 E - 0 2}$ & $\mathbf{1 . 0 6 E - 0 2}$ & $\mathbf{2 . 1 7 E - 0 3}$ & $\mathbf{2 . 8 1 E - 0 3}$ & $\mathbf{3 . 9 4 E - 0 3}$ & $\mathbf{2 . 1 5 E - 0 3}$ & $4.77 \mathrm{E}-02$ & $9.53 \mathrm{E}-02$ \\
\hline & & & & & & & $2.98 \mathrm{E}+0$ & $5.97 \mathrm{E}+0$ \\
${ }^{239} \mathrm{Pu}$ & $\mathbf{0 . 6 8 1}$ & $\mathbf{8 . 2 4 E - 0 1}$ & $\mathbf{0 . 1 5 1}$ & $\mathbf{3 . 7 8 E - 0 1}$ & $\mathbf{5 . 9 0 E - 0 1}$ & $\mathbf{3 . 5 9 E - 0 1}$ & 0 & 0 \\
\hline${ }^{241} \mathrm{Pu}$ & $\mathbf{0 . 0 0 0 9 0 5}$ & $\mathbf{0 . 0 0 4 1 9}$ & 0.000935 & $\mathbf{0 . 0 0 0 2 8 3}$ & 0.000653 & $9.79 \mathrm{E}-04$ & $7.95 \mathrm{E}-03$ & $1.59 \mathrm{E}-02$ \\
\hline${ }^{237} \mathrm{~Np}+{ }^{233} \mathrm{~Pa}$ & $\mathbf{9 . 7 9 E - 0 3}$ & $\mathbf{9 . 2 6 E - 0 3}$ & $\mathbf{2 . 0 1 E - 0 3}$ & $\mathbf{3 . 1 6 E - 0 3}$ & $\mathbf{6 . 8 4 E - 0 3}$ & $\mathbf{1 . 7 2 E - 0 3}$ & $3.28 \mathrm{E}-02$ & $6.56 \mathrm{E}-02$ \\
\hline${ }^{241} \mathrm{Am}$ & $\mathbf{1 . 9 9 E - 0 2}$ & $\mathbf{1 . 3 2 E - 0 2}$ & $\mathbf{0 . 0 0 4 2 9}$ & $\mathbf{0 . 0 1}$ & $\mathbf{0 . 0 2 0 8}$ & $\mathbf{0 . 0 0 5 1 7}$ & $7.34 \mathrm{E}-02$ & $1.47 \mathrm{E}-01$ \\
\hline
\end{tabular}


WSRC-STI-2007-00127, Rev. 1

$5 / 4 / 2007$

20 of 21

\section{(Numbers in bold are measured values others are MDAs.)}

\begin{tabular}{|c|c|c|c|c|c|c|c|}
\hline \multicolumn{3}{|c|}{ SRNL VE Glovebox Measurements } & \multirow[b]{2}{*}{${ }^{241} \mathrm{Pu}$} & \multirow{2}{*}{$\begin{array}{c}11 / 30 / 2006 \\
{ }^{237} \mathrm{~Np}\end{array}$} & \multirow[b]{2}{*}{${ }^{243} \mathrm{Cm}$} & \multirow[b]{2}{*}{${ }^{244} \mathrm{Cm}$} & \multirow[b]{2}{*}{${ }^{245} \mathrm{Cm}$} \\
\hline & ${ }^{238} \mathbf{P u}$ & ${ }^{239} \mathbf{P u}$ & & & & & \\
\hline GBA-E-1 & $3.59 \mathrm{E}-03$ & $\begin{array}{c}1.74 E+0 \\
0 \\
\end{array}$ & 1.23E-03 & 9.63E-03 & 1.09E-07 & $7.58 \mathrm{E}-04$ & $2.13 \mathrm{E}-05$ \\
\hline GBA-E-2 & $2.68 \mathrm{E}-03$ & $\begin{array}{c}1.15 E+0 \\
0\end{array}$ & $8.48 E-04$ & 4.74E-03 & 4.03E-08 & $5.67 \mathrm{E}-04$ & $1.93 \mathrm{E}-05$ \\
\hline GBA-E-3 & $6.35 \mathrm{E}-03$ & $\begin{array}{c}1.75 E+0 \\
0\end{array}$ & $6.58 \mathrm{E}-04$ & $5.89 E-03$ & 9.52E-08 & 1.34E-03 & $2.09 \mathrm{E}-05$ \\
\hline GBA-E-4 & $3.64 \mathrm{E}-03$ & $\begin{array}{c}1.90 \mathrm{E}+0 \\
0 \\
\end{array}$ & $1.48 E-03$ & $3.46 \mathrm{E}-03$ & 4.69E-08 & $7.68 \mathrm{E}-04$ & $1.95 \mathrm{E}-05$ \\
\hline GBA-E Total & $1.63 \mathrm{E}-02$ & $6.55 \mathrm{E}+00$ & $4.21 \mathrm{E}-03$ & $2.37 \mathrm{E}-02$ & $2.91 \mathrm{E}-07$ & $3.43 \mathrm{E}-03$ & $8.10 \mathrm{E}-05$ \\
\hline GBA-E Total x 2 & $3.25 \mathrm{E}-02$ & $1.31 \mathrm{E}+01$ & $8.43 \mathrm{E}-03$ & $4.74 \mathrm{E}-02$ & $5.82 \mathrm{E}-07$ & $6.87 \mathrm{E}-03$ & $1.62 \mathrm{E}-04$ \\
\hline GBA-W-1 & 3.02E-03 & 5.09E-01 & $1.60 \mathrm{E}-03$ & $3.17 E-03$ & $2.60 \mathrm{E}-08$ & 6.37E-04 & $1.64 \mathrm{E}-05$ \\
\hline GBA-W-2 & $2.12 \mathrm{E}-03$ & 4.93E-01 & $1.49 \mathrm{E}-03$ & 4.94E-03 & $3.00 \mathrm{E}-08$ & 4.47E-04 & $1.53 \mathrm{E}-05$ \\
\hline GBA-W-3 & $1.96 \mathrm{E}-03$ & $7.61 \mathrm{E}-01$ & $1.63 \mathrm{E}-03$ & 4.10E-03 & $3.56 \mathrm{E}-08$ & 4.14E-04 & $1.64 \mathrm{E}-05$ \\
\hline GBA-W-4 & $4.16 \mathrm{E}-03$ & 7.48E-01 & $6.06 \mathrm{E}-04$ & $3.25 \mathrm{E}-03$ & $2.75 \mathrm{E}-08$ & 8.78E-04 & $1.57 \mathrm{E}-05$ \\
\hline GBA-W Total & $1.13 \mathrm{E}-02$ & $2.51 \mathrm{E}+00$ & $5.33 \mathrm{E}-03$ & $1.55 \mathrm{E}-02$ & $1.19 \mathrm{E}-07$ & $2.38 \mathrm{E}-03$ & $6.38 \mathrm{E}-05$ \\
\hline GBA-W Total x 2 & $2.25 \mathrm{E}-02$ & $5.02 \mathrm{E}+00$ & $1.07 \mathrm{E}-02$ & $3.09 \mathrm{E}-02$ & $2.38 \mathrm{E}-07$ & $4.75 \mathrm{E}-03$ & $1.28 \mathrm{E}-04$ \\
\hline HEPA E-A & $6.90 \mathrm{E}-03$ & $\begin{array}{c}2.42 \mathrm{E}+0 \\
0 \\
\end{array}$ & $6.44 \mathrm{E}-03$ & $4.29 \mathrm{E}-02$ & 5.04E-07 & $1.46 \mathrm{E}-03$ & $1.07 \mathrm{E}-05$ \\
\hline HEPA E-A x 2 & $1.38 \mathrm{E}-02$ & $4.84 \mathrm{E}+00$ & $1.29 \mathrm{E}-02$ & $8.58 \mathrm{E}-02$ & $1.01 \mathrm{E}-06$ & $2.91 \mathrm{E}-03$ & $2.14 \mathrm{E}-05$ \\
\hline HEPA W-A & $1.12 \mathrm{E}-02$ & $\begin{array}{c}2.05 E+0 \\
0 \\
\end{array}$ & $5.30 \mathrm{E}-03$ & $2.85 \mathrm{E}-02$ & 3.48E-07 & 2.37E-03 & $8.62 \mathrm{E}-06$ \\
\hline HEPA W-A x 2 & $2.25 \mathrm{E}-02$ & $4.10 \mathrm{E}+00$ & $1.06 \mathrm{E}-02$ & $5.70 \mathrm{E}-02$ & $6.97 \mathrm{E}-07$ & 4.74E-03 & $1.72 \mathrm{E}-05$ \\
\hline E (GB+HEPA) & $2.32 \mathrm{E}-02$ & $8.97 \mathrm{E}+00$ & $1.07 \mathrm{E}-02$ & $6.66 \mathrm{E}-02$ & $7.95 \mathrm{E}-07$ & 4.89E-03 & $9.16 \mathrm{E}-05$ \\
\hline W (GB +HEPA) & $2.25 \mathrm{E}-02$ & $4.56 \mathrm{E}+00$ & $1.06 \mathrm{E}-02$ & $4.40 \mathrm{E}-02$ & $4.67 \mathrm{E}-07$ & $4.75 \mathrm{E}-03$ & $7.24 \mathrm{E}-05$ \\
\hline E (GB+HEPA) $\times 2$ & $4.63 \mathrm{E}-02$ & $1.79 \mathrm{E}+01$ & $2.13 \mathrm{E}-02$ & $1.33 \mathrm{E}-01$ & $1.59 \mathrm{E}-06$ & $9.78 \mathrm{E}-03$ & $1.83 \mathrm{E}-04$ \\
\hline W (GB +HEPA) $\times 2$ & $4.50 \mathrm{E}-02$ & $9.12 \mathrm{E}+00$ & $2.13 \mathrm{E}-02$ & $8.79 \mathrm{E}-02$ & $9.35 \mathrm{E}-07$ & $9.49 \mathrm{E}-03$ & $1.45 \mathrm{E}-04$ \\
\hline TOTAL X 2 & $9.13 \mathrm{E}-02$ & $2.71 \mathrm{E}+01$ & $4.26 \mathrm{E}-02$ & $2.21 \mathrm{E}-01$ & $2.52 \mathrm{E}-06$ & $1.93 \mathrm{E}-02$ & $3.28 \mathrm{E}-04$ \\
\hline & & bold & neasured & alues oth & 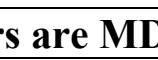 & & \\
\hline
\end{tabular}


WSRC-STI-2007-00127, Rev. 1 5/4/2007

21 of 21

\begin{tabular}{|c|c|c|c|c|c|c|c|}
\hline \multicolumn{3}{|c|}{ SRNL VE Glovebox Measurements } & \multirow[b]{2}{*}{${ }^{241} \mathrm{Pu}$} & \multirow{2}{*}{$\frac{1 / 10 / 2007}{{ }^{237} \mathrm{~Np}}$} & \multirow[b]{2}{*}{${ }^{243} \mathrm{Cm}$} & \multirow[b]{2}{*}{${ }^{244} \mathrm{Cm}$} & \multirow[b]{2}{*}{${ }^{245} \mathrm{Cm}$} \\
\hline & ${ }^{238} \mathrm{Pu}$ & ${ }^{239} \mathrm{Pu}$ & & & & & \\
\hline GBA-E-1 & $1.71 \mathrm{E}-03$ & $4.50 \mathrm{E}-01$ & $1.59 \mathrm{E}-03$ & $2.98 \mathrm{E}-03$ & $3.42 \mathrm{E}-08$ & $3.77 \mathrm{E}-04$ & $1.70 \mathrm{E}-05$ \\
\hline GBA-E-2 & $2.02 \mathrm{E}-03$ & $6.87 \mathrm{E}-01$ & $1.87 \mathrm{E}-03$ & 6.03E-03 & $4.56 \mathrm{E}-08$ & $4.44 \mathrm{E}-04$ & $1.99 \mathrm{E}-05$ \\
\hline GBA-E-3 & $1.96 \mathrm{E}-03$ & 8.66E-01 & $1.08 \mathrm{E}-03$ & 5.95E-04 & $3.85 \mathrm{E}-08$ & 4.32E-04 & $1.95 \mathrm{E}-05$ \\
\hline GBA-E-4 & $1.90 \mathrm{E}-03$ & $9.45 \mathrm{E}-01$ & $8.26 E-04$ & $1.70 \mathrm{E}-03$ & $1.92 \mathrm{E}-08$ & 4.17E-04 & $1.90 \mathrm{E}-05$ \\
\hline GBA-E Total & $7.60 \mathrm{E}-03$ & $2.95 \mathrm{E}+00$ & $5.37 \mathrm{E}-03$ & $1.13 \mathrm{E}-02$ & $1.37 \mathrm{E}-07$ & $1.67 \mathrm{E}-03$ & $7.53 \mathrm{E}-05$ \\
\hline GBA-E Total $\times 2$ & $1.52 \mathrm{E}-02$ & $5.90 \mathrm{E}+00$ & $1.07 \mathrm{E}-02$ & $2.26 \mathrm{E}-02$ & $2.75 \mathrm{E}-07$ & $3.34 \mathrm{E}-03$ & $1.51 \mathrm{E}-04$ \\
\hline GBA-W-1 & $1.76 \mathrm{E}-03$ & $3.76 \mathrm{E}-01$ & $1.63 \mathrm{E}-03$ & $3.58 \mathrm{E}-03$ & $3.51 \mathrm{E}-08$ & $3.88 \mathrm{E}-04$ & $1.71 \mathrm{E}-05$ \\
\hline GBA-W-2 & $1.49 \mathrm{E}-03$ & $2.56 \mathrm{E}-01$ & $1.36 \mathrm{E}-03$ & $2.40 E-03$ & $3.02 \mathrm{E}-08$ & $3.27 \mathrm{E}-04$ & $1.47 \mathrm{E}-05$ \\
\hline GBA-W-3 & $1.40 \mathrm{E}-03$ & $4.31 \mathrm{E}-01$ & $1.33 \mathrm{E}-03$ & 8.32E-04 & $1.54 \mathrm{E}-08$ & $3.08 \mathrm{E}-04$ & $1.39 \mathrm{E}-05$ \\
\hline GBA-W-4 & $1.49 \mathrm{E}-03$ & & $1.39 \mathrm{E}-03$ & $3.33 E-03$ & $2.25 \mathrm{E}-08$ & $3.14 \mathrm{E}-03$ & $1.52 \mathrm{E}-05$ \\
\hline GBA-W Total & $6.14 \mathrm{E}-03$ & $1.63 \mathrm{E}+00$ & $5.71 \mathrm{E}-03$ & $1.01 \mathrm{E}-02$ & $1.03 \mathrm{E}-07$ & $4.16 \mathrm{E}-03$ & $6.10 \mathrm{E}-05$ \\
\hline GBA-W Total x 2 & $1.23 \mathrm{E}-02$ & $3.25 \mathrm{E}+00$ & $1.14 \mathrm{E}-02$ & $2.03 \mathrm{E}-02$ & $2.07 \mathrm{E}-07$ & $8.33 \mathrm{E}-03$ & $1.22 \mathrm{E}-04$ \\
\hline HEPA E-A & $7.66 \mathrm{E}-03$ & $\begin{array}{c}2.61 E+0 \\
0 \\
\end{array}$ & $6.49 E-03$ & 4.64E-02 & $5.56 \mathrm{E}-07$ & $1.62 E-03$ & $1.19 \mathrm{E}-05$ \\
\hline HEPA E-A $\times 2$ & $1.53 \mathrm{E}-02$ & $5.23 \mathrm{E}+00$ & $1.30 \mathrm{E}-02$ & $9.28 \mathrm{E}-02$ & $1.11 \mathrm{E}-06$ & $3.23 \mathrm{E}-03$ & $2.38 \mathrm{E}-05$ \\
\hline HEPA W-A & $1.53 \mathrm{E}-02$ & $\begin{array}{c}2.76 E+0 \\
0\end{array}$ & $6.98 \mathrm{E}-03$ & $4.24 \mathrm{E}-02$ & 4.53E-07 & $3.23 \mathrm{E}-03$ & $1.01 \mathrm{E}-05$ \\
\hline HEPA W-A x 2 & $3.06 \mathrm{E}-02$ & $5.52 \mathrm{E}+00$ & $1.40 \mathrm{E}-02$ & $8.49 \mathrm{E}-02$ & $9.05 \mathrm{E}-07$ & $6.47 \mathrm{E}-03$ & $2.01 \mathrm{E}-05$ \\
\hline E (GB+HEPA) & $1.53 \mathrm{E}-02$ & $5.56 \mathrm{E}+00$ & $1.19 \mathrm{E}-02$ & $5.77 \mathrm{E}-02$ & $6.94 \mathrm{E}-07$ & $3.29 \mathrm{E}-03$ & $8.72 \mathrm{E}-05$ \\
\hline W (GB + HEPA) & $2.15 \mathrm{E}-02$ & $4.38 \mathrm{E}+00$ & $1.27 \mathrm{E}-02$ & $5.26 \mathrm{E}-02$ & $5.56 \mathrm{E}-07$ & $7.40 \mathrm{E}-03$ & $7.10 \mathrm{E}-05$ \\
\hline E (GB+HEPA) $\times 2$ & $3.05 \mathrm{E}-02$ & $1.11 \mathrm{E}+01$ & $2.37 \mathrm{E}-02$ & $1.15 \mathrm{E}-01$ & $1.39 \mathrm{E}-06$ & $6.57 \mathrm{E}-03$ & $1.74 \mathrm{E}-04$ \\
\hline W (GB +HEPA $) \times 2$ & $4.29 \mathrm{E}-02$ & $8.77 \mathrm{E}+00$ & $2.54 \mathrm{E}-02$ & $1.05 \mathrm{E}-01$ & $1.11 \mathrm{E}-06$ & $1.48 \mathrm{E}-02$ & $1.42 \mathrm{E}-04$ \\
\hline TOTAL X 2 & $7.34 \mathrm{E}-02$ & $1.99 \mathrm{E}+01$ & $4.91 \mathrm{E}-02$ & $2.21 \mathrm{E}-01$ & $2.50 \mathrm{E}-06$ & $2.14 \mathrm{E}-02$ & $3.16 \mathrm{E}-04$ \\
\hline & & & & & & & \\
\hline
\end{tabular}

